\title{
Pharmacotherapeutics of SARS-CoV-2 Infections
}

\author{
Bhavesh D. Kevadiya ${ }^{1} \cdot$ Jatin Machhi ${ }^{1} \cdot$ Jonathan Herskovitz ${ }^{1,2} \cdot$ Maxim D. Oleynikov ${ }^{1}$. Wilson R. Blomberg ${ }^{1} \cdot$ \\ Neha Bajwa ${ }^{3}$. Dhruvkumar Soni ${ }^{4}$. Srijanee Das ${ }^{1,2}$ - Mahmudul Hasan ${ }^{4}$. Milankumar Patel ${ }^{1}$ - Ahmed M. Senan ${ }^{5}$. \\ Santhi Gorantla ${ }^{1}$. JoEllyn McMillan ${ }^{1} \cdot$ Benson Edagwa ${ }^{1} \cdot$ Robert Eisenberg $^{6} \cdot$ Channabasavaiah B. Gurumurthy $^{1}$. \\ St Patrick M. Reid ${ }^{2}$. Chamindie Punyadeera ${ }^{7}$. Linda Chang ${ }^{8} \cdot$ Howard E. Gendelman $^{1,2,4}$
}

Received: 19 October 2020 / Accepted: 27 October 2020 / Published online: 6 January 2021

(C) Springer Science+Business Media, LLC, part of Springer Nature 2021

\begin{abstract}
The COVID-19 pandemic has affected more than 38 million people world-wide by person to person transmission of the severe acute respiratory syndrome coronavirus 2 (SARS-CoV-2). Therapeutic and preventative strategies for SARS-CoV-2 remains a significant challenge. Within the past several months, effective treatment options have emerged and now include repurposed antivirals, corticosteroids and virus-specific antibodies. The latter has included convalescence plasma and monoclonal antibodies. Complete viral eradication will be achieved through an effective, safe and preventative vaccine. To now provide a comprehensive summary for each of the pharmacotherapeutics and preventative strategies being offered or soon to be developed for SARS-CoV-2.
\end{abstract}

Keywords SARS-CoV-2 $\cdot$ COVID-19 therapeutics $\cdot$ Antivirals $\cdot$ Antibodies $\cdot$ Vaccine

\section{Introduction}

The novel coronavirus, the severe acute respiratory syndrome coronavirus 2 (SARS-CoV-2), after its first appearance in Wuhan, China, speread globally and soon it was declared the third global pandemic by zoonotic coronaviruses, successed by SARS-CoV in 2003 and Middle East respiratory syndrome coronavirus (MERS-CoV) in 2012 (Coronaviridae Study Group of the International Committee on Taxonomy of V 2020; Lu et al. 2020; Zhu et al. 2020). The disease is mainly manifeced by the acute respiratory distress syndrome (ARDS) causing pulmonary demise and uptimately death especially affecting patients

Bhavesh D. Kevadiya

bhaveshd.kevadiya@unmc.edu

1 Department of Pharmacology and Experimental Neuroscience, College of Medicine, University of Nebraska Medical Center, Omaha, NE 68198-5880, USA

2 Department of Pathology and Microbiology, College of Medicine, University of Nebraska Medical Center, Omaha, NE 68198, USA

3 Department of Pharmaceutical Sciences \& Technology, Maharaja Ranjit Singh Punjab Technical University, Bathinda, Pb, India

4 Department of Pharmaceutical Sciences, College of Pharmacy, University of Nebraska Medical Center, Omaha, NE 68198, USA with comorbid conditions like diabetes, hypertension (Machhi et al. 2020; Xu et al. 2020; Yang et al. 2020a). The SARS-CoV2 enters the lung after binding to the epithelial angiotensinconverting enzyme 2 (ACE2) receptors and spread to the distal organs including heart, liver, kidney, gastrointestinal tract and brain, to induce systemic inflammatory immune responses $(\mathrm{Gu}$ and Korteweg 2007; Grasselli et al. 2020; Meredith Wadman et al. 2020; Yuki et al. 2020). The rapidly spread of SARS-CoV2 demands immediate needs to develop containment treatment with parallel adoption of public hygiene etiquette and practice (National Institute of Health (NIH) 2020a, 2020b; Udugama et al. 2020; Wölfel et al. 2020).

5 Glycomics and Glycan Bioengineering Research Center (GGBRC), College of Food Science and Technology, Nanjing Agricultural University, Nanjing 20095, China

6 Private Citizen, Omaha, NE 68198, USA

7 The School of Biomedical Sciences and the Institute of Health and Biomedical Innovation, Queensland University of Technology and the Translational Research Institute, Brisbane, Australia

8 Departments of Diagnostic Radiology \& Nuclear Medicine, and Neurology, School of Medicine, University of Maryland, Baltimore, MD 21201, USA 


\section{Clinical Signs and Symptoms}

Infection by SARS-CoV-2 ranges in outcome severity. Among individuals testing positive for SARS-CoV-2, 56 to $88 \%$ report no symptoms at the time of testing (Arons et al. 2020; Mizumoto et al. 2020). Nonetheless, in the absence of universal screening, estimating true asymptomatic rates remains challenging. The clinical progression of COVID-19 disease is often associated with the length of the pathogen's incubation (Machhi et al. 2020). Most COVID-19 patients develop symptoms three to six days after viral exposure (Backer et al. 2020; Guan et al. 2020; Li et al. 2020b). Similarly, the median time from symptom onset to the development of pneumonia and the ARDS is up to eight days (Wang et al. 2020b). Symptom duration is 13 days (Young et al. 2020). A 14-day quarantine is recommended following exposure to SARS-CoV-2. This is in accordance with the upper limits of the virus' incubation period. Mild COVID19 , defined as no or mild respiratory compromise, is present in $81 \%$ of infected persons (Wu and McGoogan 2020). At presentation, the most common COVID-19 symptoms are fever, dry cough, and sore throat (Young et al. 2020). As disease progresses, the signs of early infection include shortness of breath, myalgias, and rhinorrhea. A minority of patients have abdominal pain, nausea or diarrhea (Cheung et al. 2020). Alternatively, smell and or taste dysfunctions are present at the onset of disease in up to $19 \%$ of patients (Giacomelli et al. 2020). SARS-CoV-2 induces aggressive respiratory pathologies in a subset of those infected. Severe disease, present in $14 \%$ of patients, is marked by dyspnea and hypoxia and can be recorded by radiographic infiltrates in $>50 \%$ of chest Xrays or CT scans (Wu and McGoogan 2020). Approximately $5 \%$ of infected individuals progress to a state of critical disease, frequently requiring treatments in an ICU. Critical COVID-19 complications encountered within the ICU include ARDS (19.6\%), arrhythmia (16.7\%), shock (8.7\%), acute cardiac $(7.2 \%)$ or acute kidney $(3.6 \%)$ injuries $(\mathrm{Wu}$ and McGoogan 2020). ARDS is marked by respiratory failure. Like other viral pneumonias, COVID-19 ARDS is managed with supplemental oxygen, prone positioning, mechanical ventilation, antiviral or glucocorticoid therapies and extracorporeal membrane oxygenation (Murthy et al. 2020; Wang et al. 2020b). Other atypical disease features can include dermatologic findings and inflammatory syndrome-like manifestations in children. Vesicular skin eruptions are described early in the disease course whereas purple nodules on peripheral digits have led to the term, "COVID toes" (Galvan Casas et al. 2020). SARS-CoV-2 infection appears milder in children, with only $73 \%$ of those who are symptomatic reporting fever, cough, or dyspnea compared to $93 \%$ of the symptomatic adults (Centers for Disease Control and Prevention (CDC) 2020a). Some pediatric COVID-19 cases reported detail gastrointestinal symptoms and myocarditis, reflective of atypical
Kawasaki's disease (Jones et al. 2020). The mortality rate of COVID-19 is between 3 and 6\% worldwide (World Health Organization (WHO) 2020b; Centers for Disease Control and Prevention (CDC) 2020b). Deaths of COVID-19 in children are rare. Among ICU patients, the mortality rate increases to $26 \%$ and more prevalent with male gender, age ( $>63$ years) and hypertension (Grasselli et al. 2020). The main causes of death is massive alveolar damage and respiratory failure with pulmonary interstitial fibrosis (Tian et al. 2020). Serologic hallmarks of terminal COVID-19 include elevated neutrophils, D-dimer, renal failure (high blood urea nitrogen and creatinine) and lymphopenia (Wang et al. 2020b). SARSCoV-2 also promotes coagulation, neutrophilia and systemic shock during acute infection, often precipitating a cytokine storm and chronic immune exhaustion (Barnes et al. 2020; Yang et al. 2020b). These events, along with hypoxia, may stress the kidneys, contributing to final multisystem organ failure (Meredith Wadman et al. 2020; Puelles et al. 2020).

\section{Pharmacology and Pharmaceutics: Antivirals and Immune Modulators}

As the global coronavirus pandemic unfolds, treatments already approved by the U.S. FDA represent the only therapeutics available to physicians. None of them are currently able to prevent the spread of the infection, and most of the available therapeutic options are adjuvants of supportive care, mainly repurposed antiviral agents, or drugs to treat the immune responses to the infection.

Remdesivir and Favipiravir Remdesivir is a well-known, novel nucleotide analogue developed initially as a treatment for Ebola and Marburg viruses. Remdesivir has an acceptable clinical safety profile. This was reported during prior clinical research activities with $\sim 500$ individuals, including healthy volunteers and patients treated for acute Ebola virus infection (Mulangu et al. 2019). Remdesivir demonstrated antiviral activity against different coronaviruses (including SARS and MERS-CoV), both in vitro and in animal studies (Sheahan et al. 2020). Recent reports showed its efficacy against SARS-CoV-2 in vitro as well (Wang et al. 2020c). Remdesivir has been evaluated in multiple clinical trials for moderate to severe COVID-19 (Sheahan et al. 2017; Grein et al. 2020). Remdesivir is given parenterally and has reported side effects that include nausea, vomiting, and serum transaminase elevations. The use of remdesivir for COVID-19 also has been described in several case series (Gilead 2020; Holshue et al. 2020; Lescure et al. 2020). In one multicenter, multinational study, 53 patients with severe COVID-19 and hypoxia received remdesivir for up to 10 days with a median of 18 days of follow-up. In this study, $68 \%$ of the patients had clinical improvement with decreased oxygen requirements and hospital discharge. Based upon these positive reports, 
remdesivir received EUA from the US FDA for COVID-19 treatment and recently extended its use in all hospitalized suspected or confirmed adults and pediatric patients irrespective of the disease severity (Beigel et al. 2020; Grein et al. 2020). The largest double blinded, randomized, and placebo controlled clinical study of remdesivir with more than 1000 patients demonstrated that mean recovery time for the remdesivir treatment group (11 days) was significantly lower compared to the placebo group (15 days) $(P<0.001)$. The study also found a non-significant lower mortality rate after 14 days in the remdesivir treatment group compared to the placebo group. Incidences of adverse effects due to remdesivir treatment were comparable to the placebo group. Secondary analysis looked at treatment efficacy among groups categorized on the eight-category ordinal scale. The most apparent benefit was seen in patients given remdesivir with a baseline ordinal score of five (requiring oxygen). Baseline ordinal scores of four (not receiving oxygen), six (receiving high flow oxygen), and seven (receiving extracorporeal membrane oxygenation or mechanical ventilation) showed wide confidence intervals. These findings underscore the importance of starting antiviral therapies before severe pulmonary disease onset that require mechanical ventilation (Beigel et al. 2020). Design and development of drug delivery systems to improve drug absorption and facilitate targeted remdesivir delivery to the lungs are at various stages of preclinical development. Such approaches include development of inhalable particles for localized drug delivery (UT News 2020). Furthermore, strategies to enhance the antiviral potency of remdesivir (higherdose regimens in combination with other antivirals or SARSCoV-2 neutralizing antibodies) and to mitigate immunopathological host responses contributing to COVID-19 severity (e.g., inhibitors of IL-1, IL-6 or tumor necrosis factor alpha $(\mathrm{TNF} \alpha)$ ), will require rigorous studies in patients with severe COVID-19 (Wang et al. 2020e). Favipiravir, an RNA polymerase inhibitor previously used for the treatment of influen$\mathrm{za}$, is now being evaluated for SARS-CoV-2 infection. In an open-labelled study, favipiravir has shortened viral clearance time and improved CXR test results in COVID-19 patients compared to the lopinavir/ritonavir (Cai et al. 2020). Both remdesivir and favipiravir are promising therapies for COVID-19.

The mechanism of action for both drugs involves the inhibition of the viral RNA translation (Fig. 1a). After encoding, genomic RNA of SARS-CoV-2 acts as a mRNA for producing two polyproteins (ppla and pp1b). Proteolytic cleavage of the polyproteins results in the production of RNA-dependent RNA polymerase (RdRP), helicase, and non-structural proteins 3, 4 \& 6 (nsp3, nsp4 \& nsp6). Nsp3, nsp4 \& nsp6 are responsible for anchoring the SARS-CoV-2 replication transcription complex by recruitment of intracellular endoplasmic reticulum membranes to form double-membrane vesicles (DMV). RdRP and helicase localize to double-membrane vesicles and drive the production of subatomic RNAs, from which the structural and accessory proteins are produced in the next phase of translation. Early testing of both remdesivir and favipiravir showed that they can inhibit RdRP and, therefore, could be useful in the management and treatment of early or mid-stage COVID-19 (Furuta et al. 2017; Gordon et al. 2020) (Fig. 1a).

Dexamethasone Dexamethasone is a potent antiinflammatory corticosteroid and its nanoformuation is well known for the development of macrophages depot after intravenous and inhalation administration (Lammers et al. 2020). The long-acting nanoformulation of anti HIV-1 drugs showed success as a macrophage-based drug carrier for anti-HIV-1 therapy compared to the free drug (Dash et al. 2020; Kevadiya et al. 2020; Kulkarni et al. 2020; Mukadam et al. 2020). Hence, this strategy might also work in COVID-19 treatment if alveolar macrophages targeting dexamethasone nanoparticles are designed (Fig. 2). A recent study on SARS-CoV-2-infected patients showed that dexamethasone decreased mortality in COVID-19 patients. The UK-based firm and the RECOVERY Collaborative Group carried out a randomized, controlled clinical trial consisting of 2140 patients receiving dexamethasone, either by oral or inhalation route, while 4321 patients received standard care. The study showed that in hospitalized COVID-19 patients, the use of dexamethasone resulted in lowered 28-day mortality among those who were receiving either invasive mechanical ventilation or oxygen alone, but not in those without respiratory support (Group RC 2020).

Hydroxychloroquine (HCQ) and Chloroquine (CQ) Despite the widespread use of HCQ and CQ to treat COVID-19, few controlled clinical trials were performed; hence, the drug benefits remain controversial (Khuroo 2020; Patel et al. 2020). While past successes were reported for the treatment of malaria, rheumatoid arthritis and systemic lupus erythematosus, toxicities were seen associated with both medicines when used at high doses during chronic administration. However, the antiviral, anti-inflammatory and anti-thrombotic activities of HCQ (Quiros Roldan et al. 2020) led to its further exploration for SARS-CoV-2 treatments (Wang and Lim 2016). In cell-based assays, both CQ and HCQ were shown to increase endosomal $\mathrm{pH}$, interfere with virus-cell binding and ACE2 receptor glycosylation, thereby inhibiting SARS-CoV-2 infection (Fig. 1b) (Wang et al. 2020c; Yao et al. 2020). However, in-contrast to cell-based efficacy, the more potent CQ analog (de Wilde et al. 2014) was found to be ineffective in SARS-CoV-2-infected Balb/c mice (Barnard et al. 2006). Mechanistic studies to address the discrepancy were performed to assess therapeutic efficacy of CQ and HCQ. In vitro Vero (kidney), Vero-TMPRSS2 and Calu-3 (lung) cells were used to test CQ and HCQ antiviral efficacy 
a

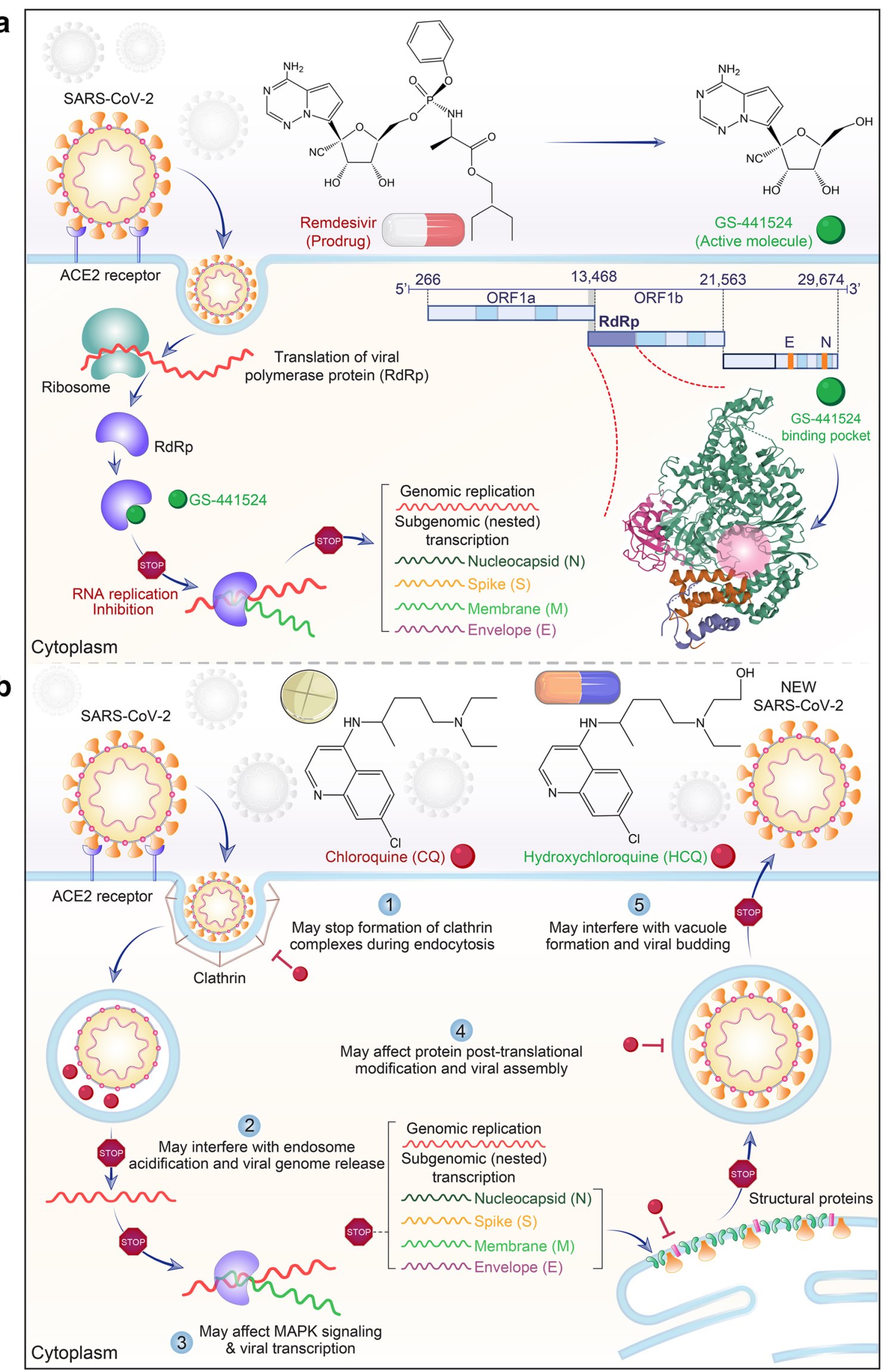


4 Fig. 1 Remdesivir, chloroquine and hydroxychloroquine for treatment of SARS-CoV-2 infection. a, Remdesivir is a phosphoramide ProTide of an adenosine nucleotide analog GS-441524. After intracellular uptake, GS-441524 converted into nucleotide triphosphate and served to inhibit viral RNA-dependent RNA-polymerase (RdRp, crystal structure adopted from (Sehnal et al. 2018)) as required for SARS viral transcription and translation. b, Chloroquine (QC) and hydroxychloroquine (HQC) are commonly used to treat malaria patients. The mechanism by which QC block virus infection is by elevating endosomal $\mathrm{pH}$ required for viral cell fusion and by interfering with the glycosylation of cellular viral receptors. Thus, it is theorized that the drugs block viral entry and post-entry infection. However, its most active steps in affecting viral pathobiology are presumed mediated by its antiinflammatory and immunomodulatory actions during the cytokine storm perpetuated by SARS-CoV-2 infections. However, the mechanism of HQC's inhibition of SARS-CoV-2 remains not completely understood and could be at any point in the viral life cycle. Potential targets may include clathrin coating during endocytosis, endosome acidification, viral transcription, trafficking, formation, and viral release/budding (1-5)

(Hoffmann et al. 2020a). The cell lines were chosen to activate the SARS-CoV-2 S and served to mediate intracellular viral entry. Notably, Vero cells utilize a $\mathrm{pH}$ dependent intracellular cysteine protease cathepsin L (catL) enzyme to activate the receptor needed for viral entry while Calu-3 cells utilize a $\mathrm{pH}$ independent plasma membrane resident serine protease (TMPRSS2) enzyme. Since cathepsin L requires an acidic environment to function and that CQ and HCQ are known to inhibit endosome-lysosomal system acidification, $\mathrm{CQ}$ and HCQ efficiently blocked SARS-CoV-2 infection of Vero but failed to block infection of Calu- 3 cells. This study underscores the importance of using appropriate assays and cell lines when screening antiviral activity of compounds that target host cellbased functions. However, due to HCQ and CQ's ability to inhibit pro-inflammatory cytokines (e.g., IL-1b, TNF- $\alpha$ and IL-2) which form major components of the cascade of events leading to ARDS in SARS-CoV-2 patients, HCQ/CQ was considered as a potential treatment (Colson et al. 2020; Multicenter collaboration group of Department of Science and Technology of Guangdong P, Health Commission of Guangdong Province for chloroquine in the treatment of novel coronavirus $\mathrm{p}$ 2020). Subsequently, however, both drugs were found to be ineffective for treatment of viral infections, including COVID-19. First, CQ treatment actually exacerbated chikungunya viral infection, with worsening of patient outcomes secondary to CQ induced delayed adaptive immune responses (Gallart et al. 1988). A single-arm, open-label trial of $600 \mathrm{mg}$ daily HCQ in 20 COVID-19 patients reported that HCQ alone, or in combination with azithromycin reduced viral load (Gautret et al. 2020a). A follow-up trial in 80 patients with HCQ and azithromycin combinations reported that $93 \%$ of patients had a negative RT-PCR result by eight days of treatment. However, both trials had no control arms (Gautret et al. 2020b). Rigorous statistical analyses by others found limited evidence for efficacy (Hulme et al.
2020; Lover 2020). A subsequent double-blind randomized clinical trial for HCQ COVID-19 treatment (ChiCTR2000029559) (Chen et al. 2020b) showed clinical resolution a day earlier than controls. Subsequent reports showed no significant differences for HCQ therapy in median duration of hospitalization, time to fever resolution, or progression of disease as measured by chest CT (Chen et al. 2020a). The largest randomized clinical trial to date enrolled 150 patients with mild COVID-19 across 16 centers in an open-label trial of HCQ versus standard of care (ChiCTR2000029868) and found no significant group differences in conversion to negative SARS-CoV-2 RT-PCR or decrease in the rate of symptom resolution (Tang et al. 2020c). Finally, a meta-analysis of all performed studies found no clinical benefits for HCQ in the treatment of SARS-CoV-2 (Shamshirian et al. 2020). Instead, worsening of clinical progression and a death were reported (Molina et al. 2020). For severe COVID-19, a double-mask, randomized phase IIb trial (NCT04323527) was performed in 81 patients who were given high compared to low doses of HCQ (600 mg/day for 10 days or $450 \mathrm{mg}$ /day for 5 days) (Borba et al. 2020). The high-dose arm was halted due to greater adverse events with prolonged QTc intervals, higher lethality, requirements for mechanical ventilation and no difference in detectable viral RNA when compared to the low-dose arm. In another observational study, 1376 patients hospitalized with COVID-19 received HCQ, but the treatment did not alter the need for intubation or death rate (Geleris et al. 2020). Taken together, HCQ alone or in combination with azithromycin show no clinical benefits in measurable outcomes for treatment of COVID-19. ClinicalTrials.gov showed 254 clinical trials involving HCQ and COVID-19, which attests to the continued interests in the investigation of this drug as potential therapy for COVID-19. However, long-term administration of HCQ was found to be associated with increased risk of cardiovascular mortality (Feng et al. 1988; Lane et al. 2020). The WHO on July 4th, 2020 recommended discontinuation of HCQ based on Solidarity Trial's International Steering Committee's recommendation (World Health Organization (WHO) 2020a). This decision was taken after their review of all completed trials (Cohen 2020).

Azithromycin and HCQ As outlined above, azithromycin in combination with HCQ should not be used for the treatment of COVID-19. In a retrospective study of 1438 COVID-19 patients hospitalized in metropolitan New York, the death rate was much higher for patients receiving HCQ and azithromycin $(25.7 \%)$ than that for HCQ alone $(19.9 \%)$, azithromycin alone $(10.0 \%)$ or neither drug $(12.7 \%)$. Furthermore, the likelihood of cardiac arrest was 2.1 times greater in patients receiving $\mathrm{HCQ}$ and azithromycin (Rosenberg et al. 2020). Both azithromycin and HCQ toxicities are related to QTc prolongation, and their combined use might have potentiated this adverse effect (Borba et al. 2020). 


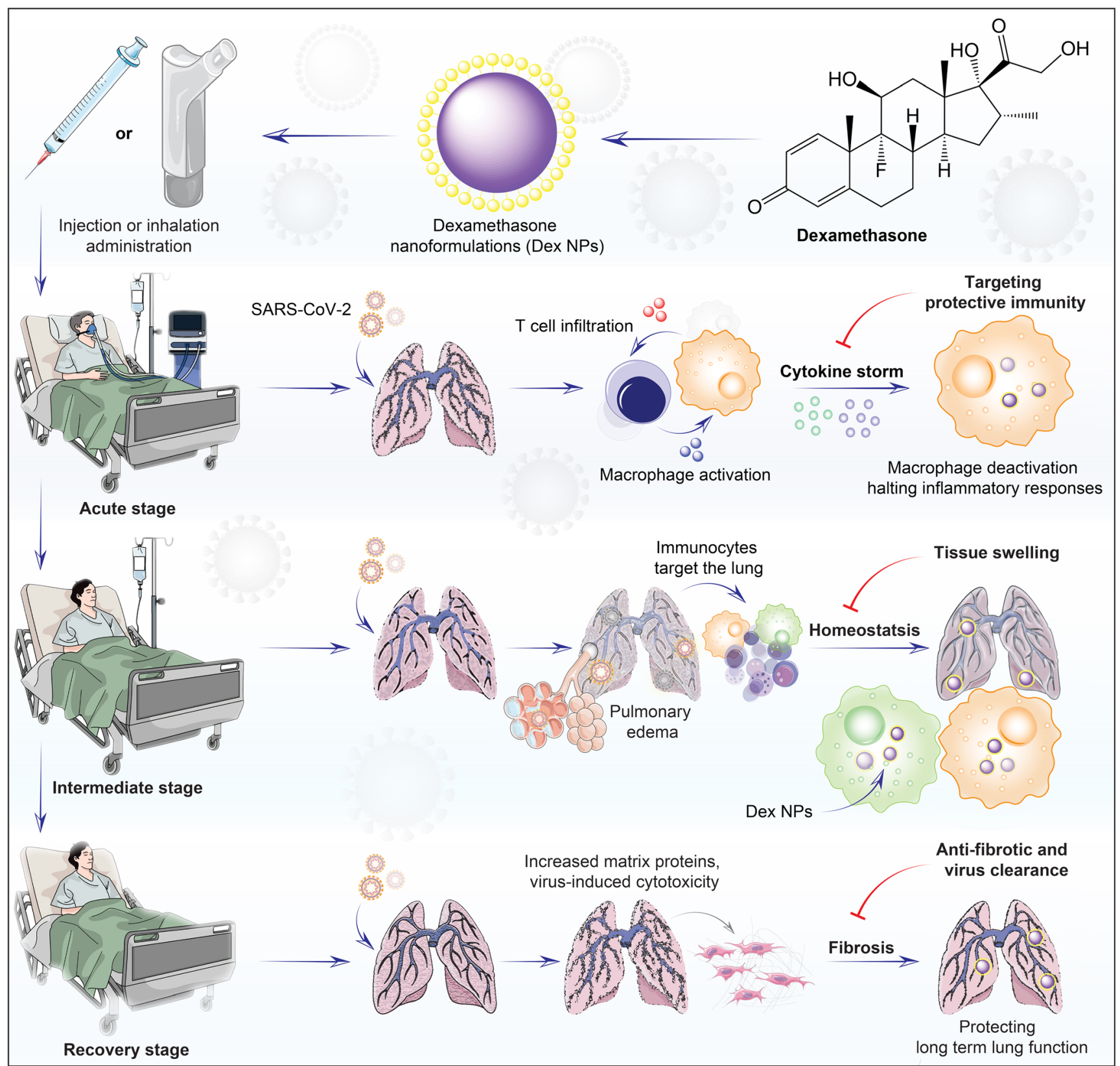

Fig. 2 Dexamethasone formulations for COVID-19 patient treatments. Nanoparticles or liposome encased dexamethasone proposed for treatment of COVID-19 patients with various stage of SARS-CoV-2 infections such as account, intermediate and recovery

Lopinavir/Ritonavir Lopinavir is a protease inhibitor that, in combination with ritonavir, has been used primarily for the treatments of HIV infection (Chandwani and Shuter 2008) and/or hepatitis C (Brayer and Reddy 2015). Combination treatment reduced risk of severe hypoxia or death in SARSCoV-infected patients (Chu et al. 2004) and improved clinical outcomes in MERS-CoV patients with interferon beta (IFN- $\beta$ ) (Arabi et al. 2018). Unfortunately, lopinavir/ ritonavir showed limited benefit for SARS-CoV-2 (Choy et al. 2020b). In a clinical trial including 199 patients with stage. This drug is given through intravenous injection or inhalation to hyper-activated immune cells, by potentiating its anti-edema activity and by exploiting its anti-fibrotic effects (Concept of this figure sourced from(Lammers et al. 2020)

laboratory confirmed SARS-CoV-2 infection, no benefit was observed for lopinavir/ritonavir compared to controls (Cao et al. 2020a).

\section{Antiviral Therapies in Development}

Targeting viral proteins as potential antiviral targets. Since the sequencing of the genome of SARS-CoV-2 was first reported, research laboratories have moved quickly to characterize critical proteins in the novel coronavirus as potential antiviral 
targets (Lefkowitz et al. 2018; Decaro and Lorusso 2020). Preliminary structural data, in silico modeling, and plaque reduction assays have elucidated five potential anti-coronavirus targets. Two of these targets (furin-like proteases and cathepsin $\mathrm{B} / \mathrm{L}$ ) are human proteins, and three targets (3CL-pro, RdRP, S protein) are viral proteins imperative for the viral life cycle (Theerawatanasirikul et al. 2020). An in-depth understanding of each target's biological role creates a framework through which informed decisions can be made regarding clinical treatment and experimental design (Masters 2006; Yan et al. 2020). The viral 3-chymotrypsin-like cysteine protease (3CL-pro) plays an essential role in the viral life cycle by cleaving polypeptides ppla and pplab at 11 sites to yield functional proteins (Ziebuhr and Siddell 1999; Barretto et al. 2005). The active site of 3CL-pro consists of a catalytic histidine/cysteine dyad and is highly conserved among SARS coronaviruses. Along with the absence of a similar human homolog, SARS-CoV-2 3CL-pro is an attractive antiviral target (Barretto et al. 2005; Stoermer 2020). The x-ray structure of SARS-CoV-2 3CL-pro, as well as the structure of the protein in complex with novel cysteine protease inhibitors, has been reported (Zhang et al. 2020). A vital component of the viral replication and transcription complex is SARS-CoV-2 RdRP, sometimes referred to as nonstructural protein 12 (nsp12) (te Velthuis et al. 2010; Yin et al. 2020). With other viral cofactors, such as nsp 7/8, RdRP catalyzes the synthesis of viral RNA components as well as the replication of the viral genome. RdRPs are one of the few conserved proteins across all RNA viruses. Several groups have reported novel RdRP inhibitors targeting different viral replication complexes (Huang et al. 2020b; Ju et al. 2020b). Most RdRP inhibitors are nucleotide analogs designed to prematurely arrest the synthesis of viral RNA by incorporating inhibitor molecules into the growing transcription (Ju et al. 2020b). Recent structural information which shows SARS-CoV-2 RdRP in complex with a nucleotide analog supports the further development of chain-terminating RdRP inhibitors (Wrapp et al. 2020; Yin et al. 2020; Zhang et al. 2020). The S protein is a transmembrane tetramer protein critical for viral cell entry. As one of four structural proteins, the S protein facilitates both host cell receptor binding as well as membrane fusion (Wrapp et al. 2020). Although the receptor-binding domain is variable among coronaviruses, the membrane fusion domain of S protein is highly conserved, which presents this region as an attractive antiviral target (Baig et al. 2020; Srinivasan et al. 2020; Wrapp et al. 2020). Biomimetic peptides that inhibit viral envelope fusion may prove to be effective therapeutics in COVID-19 treatment (Tang et al. 2020b). Antigens derived from the $\mathrm{S}$ protein, which boost recognition of the virus by immune cells or the development of monoclonal antibodies that bind to the coronavirus S protein and block the interaction with a human cell, are becoming an important field of research (NCT04334980, NCT04283461, NCT04341389, NCT04299724, NCT04276896).
Blocking the ACE-2 Receptor SARS-CoV-2 S protein binds specifically to human ACE-2 receptor, and this interaction contributes significantly to the viral tropism (Yan et al. 2020). However, recent studies showed that proteolytic cleavage of $\mathrm{S}$ protein by host proteases may also strongly influence SARS-CoV-2 tropism (Hoffmann et al. 2020b; Yan et al. 2020; Zhang et al. 2020). ACE-2 is highly expressed in type 2 alveolar cells found in the lungs. However, ACE- 2 receptors are also found in many extrapulmonary tissues, including heart, kidney, endothelium, intestinal tissues and brain (Hamming et al. 2004; Baig et al. 2020). The interface between $\mathrm{S}$ protein and ACE-2 is a potential drug target (Yan et al. 2020). Hesperidin, a compound which has shown promise during a recent computational study, is predicted to bind with the binding interface of the S protein/ACE-2 complex and disrupt this protein-protein interaction (Wu et al. 2020). Two pathways for ACE-2 receptor-mediated viral cell entry have been suggested and each presents new antiviral targets (Yan et al. 2020). Viral S protein requires cleavage by host proteases in order to initiate fusion. Human type II transmembrane serine proteases (TTSPs) and furin-like proteases (FLP) have been implicated as essential regulators of viral entry via an, "early" plasma membrane route (Duda et al. 2004; Hantak et al. 2019; Hoffmann et al. 2020b). Proteolytic cleavage of S protein induces a conformational change that enables viral envelope fusion only after binding to ACE-2 receptors. Thus, any antiviral therapeutics targeting host TTSPs or FLPs may show greater efficacy in combination with fusion inhibitors (Hantak et al. 2019; Hoffmann et al. 2020b). The virus utilizes the second viral entry mechanism, or, "late" pathway, in the absence of TTSPs (Hantak et al. 2019; Tang et al. 2020b). After binding to ACE-2 receptors, the viral particle may be brought into the cell through an endocytic pathway where acidic conditions activate early endosomal proteases such as cathepsin B or the late endosomal protease cathepsin L. In the absence of TTSPs, this endocytic route may have a significant impact on disease pathogenesis (Hantak et al. 2019; Tang et al. 2020b). In an in vitro study comparing cell entry inhibition by TTSP inhibitors, a combination of endosomal $\mathrm{pH}$ modulators and cathepsin $\mathrm{B} / \mathrm{L}$ inhibitors showed the most significant efficacy by targeting both the early and the late viral entry pathways (Hoffmann et al. 2020b). Thus TMPRSS- 2 plays an essential role in viral cell entry and spread and therefore serves as a potential therapeutic target. This finding warrants further experimental and clinical considerations regarding acute COVID-19 treatment strategies.

Camostat Mesylate TMPRSS-2 is a serine protease that governs $\mathrm{S}$ protein priming in coronaviruses and is essential for virus-host cell entry. Camostat mesylate, an inhibitor of TMPRSS-2, is effective against SARS-CoV and prevents its spread and pathogenesis (Kawase et al. 2012). A similar 
mechanism is expected against MERS-CoV as well (Rabaan 2017). A recent study identified the role of TMPRSS- 2 in SARS-CoV-2 cell entry and camostat mesylate effectively abrogated viral infection in vitro (Hoffmann et al. 2020b). Earlier clinical trials on camostat mesylate against dyspepsia associated with non-alcoholic mild pancreatic disease showed mild, but no severe side effects (Sai et al. 2010), indicating its safety. Currently, clinical trials are ongoing to assess camostat mesylate alone in mild to severe COVID-19 patients (NCT04353284, NCT04321096). Other clinical trials are registered to determine efficacy of camostat mesylate in combination with HCQ (NCT04338906, NCT04355052).

Recombinant human ACE-2. As SARS-CoV-2's S protein has a strong binding affinity to human ACE-2 receptors, it can serve as an entry port for the coronavirus (Hoffmann et al. 2020b; Wang et al. 2020d). Therefore, the delivery of an excessive soluble form of an ACE-2 may competitively bind with SARS-CoV-2 and not only neutralize the virus, but also rescue cellular ACE-2 which regulates the renin-angiotensin system to protect the lungs from injury. One small study has found recombinant human ACE-2 to be safe with no adverse hemodynamic effects in healthy subjects (Khan et al. 2017). Although, antiviral agents can improve pathology, research is ongoing in search of better candidates to prevent disease spread.

\section{Targeting Immune Responses against SARS-CoV-2}

Harnessing immunity to suppress or eliminate COVID-19 is an adjunctive, but potentially potent therapeutic approach (Golonka et al. 2020). For example, SARS-CoV-2 ORF3b is a potent interferon (IFN) antagonist. Thus, the ability to suppress induction of type I IFN has been explored beyond what is stimulated by SARS-CoV alone (Konno et al. 2020). However, IFN commonly has a paradoxical effect on viral growth; hence, whether to stimulate or suppress immune responses is a notable question (Jamilloux et al. 2020). Indeed, $5-15 \%$ of COVID-19 patients who respond to SARS-COV-2 infection with robust innate immune responses showed excessive production of cytokines beyond IFNs. This, "cytokine storm" can lead to hyperactivation of the defense mechanisms with vascular permeability, multiorgan failure and death. The cytokine profiles of serum from some patients with moderate to severe COVID-19 are similar to what was reported for the macrophage activation syndrome (MAS) (Pedersen and Ho 2020). Pro-inflammatory cytokine produced by a variety of cell types, including lymphocytes, monocytes, and fibroblasts (Choy et al. 2020a; Liu et al. 2020). Specifically elevated levels of interleukin-1, 6 (IL-1 and IL-6), C-reactive protein, $\mathrm{D}$-dimer and ferritin are readily detected in patients with COVID-19 disease (Huang et al. 2020a; Wang et al. 2020b). Several immune-based therapies directed at modifying COVID-19 under investigation include those that target the virus (convalescent plasma) or modulate the immune response (IL-1 or IL-6 blockers) and can be seen below.

IL-6 Pathway Inhibitors SARS-CoV infection induces IL-6 expression from bronchial epithelial cells (Yoshikawa et al. 2009). Elevations in IL-6 levels mediate the severe systemic inflammatory responses in patients with SARS-CoV-2 infection. COVID-19-associated systemic inflammation and hypoxic respiratory failure is associated with the, "cytokine storm", including marked increases in the levels of IL-6. Tocilizumab is an IL-6 receptor inhibitor used for rheumatic diseases and cytokine release syndrome. Case reports have described good outcomes with tocilizumab in patients with COVID-19 (Luo et al. 2020; Michot et al. 2020), but systematic evaluation of the clinical impact of tocilizumab on COVID-19 has not yet been published. Treatment guidelines from China's National Health Commission include the IL-6 inhibitor tocilizumab for patients with severe COVID-19 and elevated IL-6 levels. Tocilizumab, as well as sarilumab and siltuximab, which also target the IL-6 pathway, are being evaluated in clinical trials (Choy et al. 2020a; Khan et al. 2020).

Interleukin-1 Inhibitors SARS-CoV-2 infection triggers an exacerbated host immune response and the role of proinflammatory cytokine storm is now well established. Targeting or suppressing proinflammatory cytokine IL-1 could be effective in COVID-19 patients to control ARDS and avoid mechanical ventilation (National Institute of Health (NIH) 2020a; Jamilloux et al. 2020; Pedersen and Ho 2020). IL-1 inhibitor anakinra is currently being tested for the treatment of COVID19. Anakinra is a recombinant human IL-1 receptor antagonist. It is approved for the treatment of rheumatoid arthritis, and used off-label for different inflammatory conditions and severe chimeric antigen receptor $\mathrm{T}$ cell (CAR-T)-mediated cytokine release syndrome (CRS) and MAS (National Institute of Health (NIH) 2020b). A case series of anakinra use in moderate to severe COVID-19 pneumonia was published recently (Aouba et al. 2020). In this study, anakinra was found to be safe and reduced the risk of hemophagocytic lymphohistiocytosis in patients along with improved oxygen flow. Overall, anakinra showed improved clinical outcomes. In another case report from Italy, a critical COVID-19 patient was successfully treated with anakinra, with reduced inflammatory markers and improving respiratory functions (Filocamo et al. 2020). Fifteen ongoing clinical trials on anakinra in COVID19 patients are registered on ClnicalTrials.gov.

Interferons (IFNs) As the COVID-19 pandemic ensues, opposing findings characterizing the roles of interferon-based pathogenesis and therapies continue to emerge. What remains clear, however, is that anatomical location, duration of 
infection, and timing of treatment significantly skew how SARS-CoV-2 infection progresses in the presence of interferons. Accordingly, numerous clinical trials explore the utility of early treatment with type I or type III interferons in improving outcomes for COVID-19 patients. Interferons serve as prototypical signaling proteins of the innate immune system whose paracrine release aims to protect neighboring cells from microbial invasion or metastasis. Individual interferons are divided into three types based on their abilities to bind common receptors. Type I interferons (IFN- $\alpha$, IFN- $\beta$, IFN- $\varepsilon$, IFN- $\omega$ ) and type III interferons (IFN- $\lambda_{1-4}$ ) demonstrate antiviral activities, whereas type II interferon (IFN- $\gamma$ ) promotes systemic Th1 and cytotoxic T lymphocyte responses. Release of IFNs by virally infected cells signals neighboring cells to destroy RNA and reduce protein translation, induce apoptosis, and upregulate major histocompatibility complex molecules as well as various cytokines that cumulatively trigger immunocyte-based clearance. These various processes are mediated by interferon-stimulated genes (ISG) that trigger downstream signaling cascades. Much of the confusion over whether interferons directly contribute to COVID-19 disease stems from patient data. Sera from SARS$\mathrm{CoV}$-2-infected patients and lung tissue explants challenged ex vivo revealed low levels of types I and III interferon proteins (Blanco-Melo et al. 2020; Chu et al. 2020). Similarly, transcriptional profiling of nasopharyngeal swab and bronchioalveolar lavage samples from these patients did not detect upregulation of interferon types I and III mRNA (Lieberman et al. 2020; Zhou et al. 2020c). Nonetheless, these latter studies also implicate interferon-stimulated gene pathways (notably OAS1-3 and IFIT1-3) as contributing to the cytokine storm. Two rationale may explain induction of ISG in the absence of elevated type I and III interferon levels: Firstly, SARS-CoV-2 may trigger type II interferon protein production. Higher circulating IFN- $\gamma$, was readily measured in symptomatic adults and acute multisystem inflammatory syndrome in children with COVID-19 (Carter et al. 2020; Montalvo Villalba et al. 2020). Secondly, ACE2 is an interferon response network gene as identified in nasal epithelia of highly-expressing interferon subjects (Sajuthi et al. 2020) and its upregulation may potentiate even greater SARS-CoV-2 infection set points. These clinical findings suggest that although elevated type I and III interferons are not directly observed in COVID-19 patients, interferon stimulated genes are nonetheless triggered.

Laboratory studies elucidate how SARS-CoV-2 may induce and elude host interferon responses. Model systems characterizing SARS-CoV-2 infection in the lung reveal a causal nature to type I interferon production. RNA-Seq profiling of ciliated bronchial epithelial cells found upregulation of interferons (types I and III) and IL-6 after SARS-CoV-2 exposure, which potentiated the infection to spread to neighboring basal and club cells (Ravindra et al. 2020). Human ACE2- expressing transgenic mice recapitulated increased interferons in lung infiltrates following SARS-CoV-2 infection (Winkler et al. 2020), whereas knockout of the type I interferon receptor (ifnar ${ }^{-1-}$ ) attenuated this response (Israelow et al. 2020). Gastrointestinal symptoms observed in approximately $18 \%$ of COVID-19 patients has prompted investigations into SARS-CoV-2 pathogenesis in the colon. Type I (and to a lesser degree, type III) interferon receptor knockout prevented the establishment of SARS-CoV-2 infection in colon carcinoma T84 cells (Stanifer et al. 2020). After lung dendritic cells were exposed to viral RNA, secreted IFN- $\lambda$ induced mucosal barrier damage leading to lethal bacterial superinfection (Broggi et al. 2020). The discrepancy between low interferons observed in patients and pathogenic levels encountered in these models can, at least partially, be explained by exploring how SARS-CoV-2 has adapted to blunt interferon responses in human hosts. Interference has been described at three levels: prior to ISG-signaling, before nuclear localization, or post-translationally. SARS-CoV-2 Orf9b interacts with adaptor protein TOM70, which prevents cytoplasmic pattern recognition receptors RIG-I or MDA5 from signaling for interferon responses (Jiang et al. 2020). Alternatively, the Cterminus of Orf6 antagonizes STAT1 nuclear translocation, again precluding the production of interferon (Lei et al. 2020). Finally, the virus' papain-like protease (PLpro), which generates a functional replicase complex, attenuates type I interferon responses by cleaving two complexed ISG proteins (Shin et al. 2020). In summary, these datasets enable investigation of particular immunologic responses following SARS$\mathrm{CoV}-2$ exposure, yet their utility in recapitulating the full depth of COVID-19 pathogenesis in humans requires additional investigation. Medical treatment using interferon for COVID-19 largely relies on early intervention for therapeutic success. In vitro pretreatment with type I interferons (IFN- $\alpha$ (Felgenhauer et al. 2020) or IFN- $\beta$ (Lei et al. 2020; Shuai et al. 2020) reduced SARS-CoV-2 infection in Calu-3 lung cancer cells by approximately $33 \%-75 \%$. IFN- $\beta$ further limited Caco- 2 colorectal adenocarcinoma cells to $<1 \%$ of control infection levels (Shuai et al. 2020). Coronavirus replication can be suppressed by IFN- $\beta$ synthesized from the cell. However, coronaviruses have evolved mechanisms to escape interferon mediated growth inhibition by specifically preventing the induction of IFN- $\beta$ (Spiegel et al. 2005). In such condition, treatment with exogenous IFN- $\beta$ can be useful to attenuate virus replication. IFN- $\beta$ demonstrated protection of Vero 6 cells from infection with highly pathogenic coronavirus strains including SARS-CoV, MERS-CoV and SARS-CoV-2 (Mantlo et al. 2020; Synairgen 2020). Viral control using type I interferons has also been observed clinically. Currently, a phase-II clinical trial on the inhaled formulation of IFN- $\beta$, SNG001, in COVID-19 patients is ongoing (NCT04385095). An uncontrolled exploratory study in Wuhan, China revealed that treatment with nebulized 
IFN- $\alpha 2 b$ along with the antiviral, arbidol, significantly reduced the duration of detectable virus in the upper respiratory tract and reduced the duration of blood inflammatory markers (Yin et al. 2020). Two randomized drug trials utilizing IFN- $\beta 1$ a as part of lopinavir-ritonavir-based regimens demonstrated clinical benefit. In one study, Iranian inpatients receiving combination therapy observed a reduced 28-day mortality and increased 14-day discharge rate (Dastan et al. 2020). A larger multicenter phase 2 clinical trial in Hong Kong, wherein COVID-19 patients were hospitalized on average 5 days after symptom onset, reported shortened time until SARS-CoV-2 negative nasopharyngeal swabs were collected (Hung et al. 2020). Type III interferon may also prove beneficial in abrogating coronavirus infection. Pretreatment of primary human airway epithelia with PEG-IFN- $\lambda_{1}$ or human intestinal epithelial cells with IFN- $\lambda$ reduced viral replication by $5 \operatorname{logs}$ and 2 logs, respectively (Dinnon et al. 2020; Stanifer et al. 2020). Prophylactic administration of PEG-IFN- $\lambda_{1}$ to mice challenged with a murine form of SARS-CoV-2 also exhibited 90\% reduction in recovered virus in the lungs (Stanifer et al. 2020). Whether such benefits will extend to humans remains to be seen. PROTECT (NCT04344600) is a phase $2 \mathrm{~b}$ prospective, randomized, single-blind, placebocontrolled clinical trial currently recruiting patients to assess whether single subcutaneous injection of PEG-IFN- $\lambda_{1}$ prevents SARS-CoV-2 infection among individuals with known household exposure to COVID-19. Overall, early intervention with interferons may aid in the arsenal of therapies necessary to prevent SARS-CoV-2 infection, both within an individual and from spreading to others.

Tableted Heat-Inactivated Plasma This is another alternative option which may lead to faster recovery in patients with COVID-19. One clinical trial aims to administer once daily pills of therapeutic vaccine made from COVID-19 donor heatinactivated plasma to the healthy volunteers for 15 days. The primary objective of this study is to evaluate safety and characterize the immune responses in the recipients. By presenting both heat-inactivated virus and human antibodies, this trial hopes to elicit protective immune responses (NCT04380532).

Anticoagulants Recent reports emphasize the risk of coagulopathy in severely ill COVID-19 patients, especially in those with comorbid conditions such as cancer, congestive heart failure, hypertension and obesity (Barnes et al. 2020; Kollias et al. 2020). For instance, among 183 hospitalized patients, disseminated intravascular coagulation (DIC) was much more common $(71.4 \%)$ in patients who died from COVID-19 than the survivors $(0.6 \%)$ (Tang et al. 2020a). The coagulopathy may be related to the cytokine storms, and elevated D-dimer levels that were reported in patients with cerebrovascular events, both thrombotic and hemorrhagic, as well as concurrent peripheral thrombotic events, such as deep vein thrombosis or pulmonary emboli (Tang et al. 2020a). Recently, the Anticoagulation Forum, a North American organization of anticoagulation providers, evaluated the increased risk of venous thromboembolism (VTE) in COVID-19 patients, and provided guidelines regarding the use of anticoagulation therapies for their management (Barnes et al. 2020). In severely ill COVID-19 patients, daily D-dimer monitoring is recommended to surveil VTE severity and provide prognosis and adjustment for dosing of anticoagulants (Barnes et al. 2020). For COVID-19 patients presenting a risk for VTE, thromboprophylaxis or a full course of therapeutic anticoagulation is recommended (Barnes et al. 2020; Kollias et al. 2020).

Transformative Immunity Bacillus Calmette-Guérin (BCG) is a live attenuated vaccine that was developed against tuberculosis at the Institute Pasteur in Paris during early 1921 (Luca and Mihaescu 2013). BCG has been the most used vaccine in the world, with around 130 million children vaccinated every year to reduce infant mortality and the incidence of tuberculosis. Later, BCG vaccination was reported to decrease susceptibility to unrelated infectious agents such as respiratory tract infections (Butkeviciute et al. 2018; Moorlag et al. 2019). BCG also has been shown to provide non-specific protection against other respiratory tract infections which might lower the rate of absenteeism in health care workers (NCT04328441). Experimental studies have shown that BCG reduced viral titers of influenza A virus in mice, an effect dependent on macrophages (Spencer et al. 1977). BCG vaccination also protected mice from herpes simplex virus type 2 (HSV2) infection (Starr et al. 1976). BCG vaccination resulted in enhanced production of proinflammatory cytokines, such as IL- $1 \beta$, TNF- $\alpha$ and IL-6, when monocytes from vaccinated healthy individuals were stimulated ex vivo with unrelated pathogens. These effects are mediated by transcriptional, epigenetic and metabolic reprogramming of the myeloid cells for improved anti-microbial responses (Netea et al. 2016). The long-term innate immune memory seen with BCG vaccination has been termed, "trained immunity". Upon challenge with unrelated pathogens, these trained innate immune cells promote host defense. Thus, BCG vaccination provides significant protection against multiple viral infections. Lower infection rates and reduced mortality from COVID-19 were observed in countries that practice BCG vaccination, although a causal relationship has not been established (Miyasaka 2020). Based on these previous observations, BCG vaccination is hypothesized to be a potent preventive measure against SARS-CoV-2 infection, and it may well be a bridge until a specific COVID- 
19 vaccine is developed (O'Neill and Netea 2020). Indeed, trials assessing the efficacy of BCG vaccination to prevent COVID-19 are currently being carried out in the Netherlands, Australia, Greece, and the United States, with more being planned in many other countries. Unlike influenza, SARS-CoV-2 seems to disproportionately affect older populations as compared to children. One hypothesis for this disparate manifestation of COVID-19 is that cross protective antibodies generated in response to the measles vaccine may be protecting the children. In vivo experiments showed recombinant measles vaccine fully protected animals from intranasal challenge with SARS-CoV. A clinical trial aims to test this hypothesis by immunizing health care workers with the measles vaccine and tracking the rates of infection (NCT04357028).

\section{Vaccines (an Overview)}

The limited antiviral medications and their variant therapeutic efficacies are pressing for the development of a vaccine to provide global immunity against SARS-CoV2 virus (Lurie et al. 2020). Vaccine development is an extended process that typically involves five to ten years of rigorous pre-clinical trials, followed by clinical trials. However, COVID-19 is changing that paradigm. This is based on the critical needs for effective vaccines; therefore, the medical, scientific, and administrative stalwarts

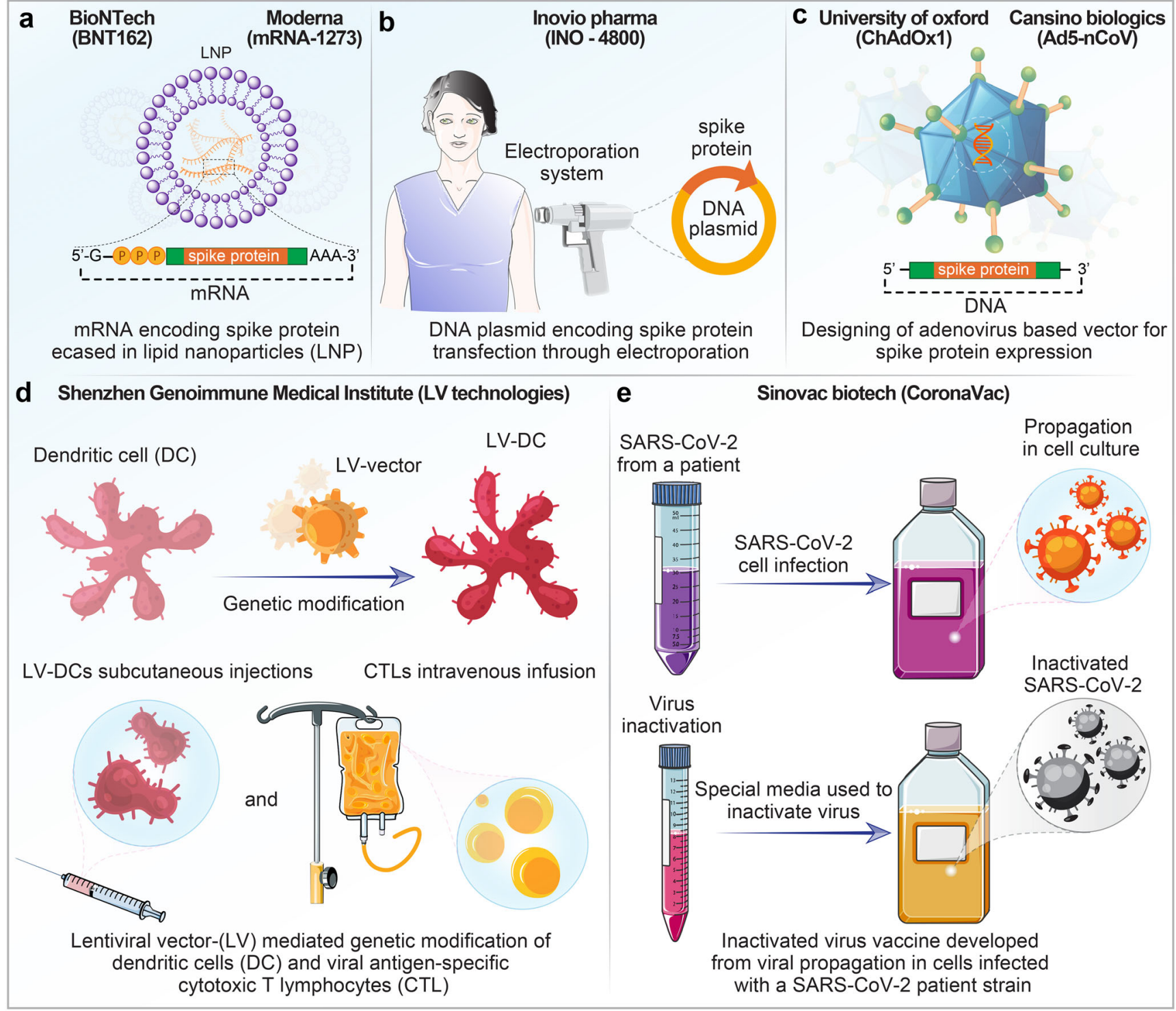

Fig. 3 Current vaccine strategies for SARS-CoV-2. Clockwise from top left: (a), delivery of mRNA encoding viral protein through lipid nanoparticle; (b), direct delivery(electroporation) of plasmid DNA encoding viral protein; (c), human and chimpanzee adenovirus-based delivery of DNA encoding viral protein; (d), injection of inactivated viral vector; (e), injection of genetically modified immune cells 
have moved with alacrity to reschedule the vaccine development regime and simultaneously develop multiple vaccine candidates with accelerated clinical trials. For the first time in the vaccine development history, and only 63 days after the publication of the sequence of COVID19 on January 12th, 2020 (European Centre for Disease Prevention and Control (ECDC) 2020), two vaccines, mRNA1273 (NCT04283461) and Ad5-nCoV (NCT04313127) entered phase-I human clinical trial. Currently, the 213 vaccines (Callaway 2020; Milken Institute 2020) developed by academic research teams and pharmaceutical companies against SARS-CoV-2 worldwide have offered divergent technologies for vaccine development, several of which have never been used in a licensed vaccine. These various platforms, along with the human clinical trial forerunners, are described based on the approach and composition of the vaccine (Fig. 3).

Protein-Based Vaccines Most vaccines now in development are protein-based. Researchers use viral proteins either as fragments or as protein shells. Protein subunit vaccines use the $\mathrm{S}$ protein as a whole or its receptor-binding domain as an antigen to elicit antibody responses.

Viral-Vector-Based Vaccines Another protein-based vaccine includes virus-like particles (VLPs). These particles are virus shells devoid of viral genomic RNA that mimic the coronavirus structure but are not infectious. The next most common vaccines are viral vectors or VLPs. These use genetically engineered non-pathogenic viruses (for example, measles or adenovirus) that produce coronavirus proteins and can be one of two types: The first can replicate within cells and the second cannot. For those that can replicate in the cells, key genes known to be pathogenic are disabled. One of the forerunner candidates, Ad5nCoV, developed by CanSino Biogenics, Beijing Institute of Biotechnology, and Canadas National Research Council, has already begun phase-II clinical trials as of April 12th, 2020 (NCT04341389). Built upon CanSinoBIO's adenovirus-based viral vector vaccine technology platform, $\mathrm{Ad} 5 \mathrm{nCoV}$ is a genetically engineered vaccine candidate with the replication-defective Adenovirus of the human serotype 5 (AdHu5) as the vector for expressing SARSCoV-2 S protein. A notable limitation of the use of such human adenovirus-based vectors is that a significant portion of the population is immune to the virus as a result of previous natural infections. Thus, host immunity could lead to the persistent production of neutralizing antibodies and blunt the vaccine's effectiveness (Chirmule et al. 1999). Adoption of simian adenoviral vectors, to which the human population is less exposed, has circumvented this problem (Tatsis et al. 2006). ChAdOx1, another non-replicating viral vector candidate developed by the University of Oxford, uses a vector platform derived from chimpanzee adenovirus Y25 to express
SARS-CoV-2 S protein and started human Phase-I/II clinical trials as of April 23rd, 2020 (NCT04324606).

Nucleic Acid-Based For these vaccines, S protein-expressing DNA or RNA plasmids are injected into the cell which replicate and strengthen the natural physiological immune response via targeted $\mathrm{T}$ cell and antibody responses. Although the RNA and DNA-based vaccines are safe and easy to develop, they are unproven in clinical trials, as no licensed vaccine has used this platform to date (Rauch et al. 2018). BNT-162 developed by BioNTech, Fosun Pharma, and Pfizer, is an RNA-based vaccine candidate that entered phase-I clinical trials on April 29th,2020 (NCT04368728). This is a unique approach in that four mRNA vaccine candidates (a1, b1, b2, c2) are screened simultaneously. Two candidates have nucleoside modified mRNA (modRNA), one has uridine containing mRNA (uRNA) and one has self-amplifying mRNA (saRNA). Two encode the large S sequence while the other two encode the smaller optimized receptor-binding domain (RBD) from S (Carlson 2020). The mRNA is then encapsulated in a lipid nanoparticle formulation. The novel design of the clinical trial allows for the simultaneous evaluation of safety, immunogenicity, and the optimal dose level. This approach drastically cuts the pre-clinical phase to less than four months and, as a result, rapidly accelerates development (Biusinesswire 2020). The other lead vaccine candidate, mRNA-1273, developed by Moderna and the US National Institute of Allergy and Infectious Diseases, is a novel lipid nanoparticle (LNP)-encapsulated mRNA-based vaccine that encodes for a full-length, prefusion stabilized $\mathrm{S}$ protein of SARS-CoV-2 (NCT04283461). INO-4800, an interesting vaccine developed by Inovio Pharmaceuticals, CEPI, Korea National Institute of Health and International Vaccine Institute, is a DNA-based vaccine candidate that entered phase-I clinical trials on April 3rd, 2020 (NCT04336410). This platform uses the innovative technology of cellectra ${ }^{\circledR}$, Inovio's proprietary platform, which uses a novel hand-held device that utilizes a brief electrical pulse to reversibly open small pores in the cells and allow plasmid vaccine candidate to elicit a robust immune response intracellularly (International Vaccine Institute 2020).

Virus One form of virus-based vaccine uses viruses that have been chemically attenuated by formaldehyde or heat. This is a well-established process employed in many now current vaccines. They are easy to prepare, develop, and considered safe. Sinovac biotech developed a vaccine candidate that went on phase-I/II clinical trial on April 16th, 2020 (NCT04352608) in Xuzhou, China, and another phase-I/II clinical trial on May 20th, 2020 (estimated) (NCT04383574) in Renqiu, China. This vaccine uses inactivated clinical strains of SARS-CoV-2 fused with alum to induce an immune response. Another form, live attenuated vaccines, are viruses that have 
weakened replication or viral protein production due to mutations generated when grown in animal or human cell lines. These attenuated vaccines provide a robust immune response, but have a potential reversion to virulence (Roper and Rehm 2009).

Other Innovative Platforms Non-viral nanoparticle-mediated delivery of gene-encoded antibody vaccines, replicating bacterial vectors expressing multiple SARS-CoV-2 antigens and heat shock protein fused to avidin self-assembling vaccines are some other innovative vaccine platforms in the preclinical pipeline. Another important platform uses lentiviral vectors to genetically modify components of immune cells, such as antigen-presenting cells and dendritic cells, to alter SARS-CoV-2 immune mediated responses. LV-SMENP DC is a novel lentiviral-based dendritic cell and $\mathrm{T}$ cell vaccine candidate developed by Shenzhen Geno-Immune Medical Institute which went into phase-I/II clinical trial on March 24th, 2020 (estimated) (NCT04276896). This vaccine modifies dendritic cells using lentiviral vectors expressing SARS-CoV-2 minigene SMENP and induces expression of SARS-CoV-2 antigens and immune-modulatory genes. The vaccine uses cytotoxic $\mathrm{T}$ lymphocytes, which get activated by the SARS-CoV-2 specific antigens presented on the lentivirus modified-dendritic cells. Antigen-specific cytotoxic T cells will be injected intravenously while the lentivirusSMENP-dendritic cell (LV-SMENP DC) vaccine will be subcutaneous (NCT04276896).

Neutralizing and Functional Antibodies The US FDA is accepting investigational new drug applications to use convalescent plasma for patients with severe or life-threatening COVID-19 (US Food and Drug Administration (US FDA) 2020a). The pathways to achieve these applications include clinical trials, expanded access programs, and individual emergency use. The use of convalescent plasma has been described, "just in case series" (US Food and Drug Administration (US FDA) 2020a; Duan et al. 2020). In a randomized clinical trial enrolling 103 patients, transfusion of convalescent plasma did not improve clinical condition in severe or life threatening COVID-19 patients compared to the standard treatment. This trial was terminated early, before reaching the target enrollment of 200 patients, which might have contributed to the negative results ( $\mathrm{Li}$ et al. 2020a). One case series described the administration of plasma from donors who had recovered entirely from COVID-19 to 5 patients with severe COVID-19 who were on mechanical ventilation and presented with persistently severe viral symptoms despite investigational antiviral treatment (Shen et al. 2020). The recipients showed decreased nasopharyngeal viral load, decreased disease severity score, and improved oxygenation by 12 days after the transfusion. In another study at the Houston Methodist hospital, 25 patients with severe and/or life threatening COVID-19 disease were transfused with the convalescent plasma obtained from confirmed SARS-CoV-2infected and fully recovered donors. Seven days after transfusion, $36 \%$ of the patients clinically improved and $28 \%$ of the patients were discharged after complete recovery. 14 days after transfusion, clinically improved patients increased to $76 \%$ and $44 \%$ of patients were discharged. No adverse events were observed following plasma transfusion (Salazar et al. 2020). This study has been extended and 74 critically ill COVID-19 patients were treated, 50 of whom were discharged from the hospital after recovery (News Wise 2020). The convalescent plasma therapy outcomes in COVID-19 patients were very similar to the compassionate-use of remdesivir. Earlier this year, the US government initiated an Extended Access Program for convalescent plasma, with funding from the HHS' Biomedical Advance Research and Development Authority (BARDA) in collaboration with Mayo Clinic and have transfused more than 70,000 COVID-19 patients with convalescent plasma. After significant reduction in mortality in COVID-19 patients and no observed side effects, U.S. FDA recently issued an EUA for convalescent plasma as a promising treatment of COVID-19 (US Food and Drug Administration (US FDA) 2020b). However, these findings do not establish a causal effect; therefore, further studies are required to determine the efficacy of convalescent plasma. Finding appropriate donors and establishing testing that validates the neutralizing activity of the plasma poses logistical challenges (Duan et al. 2020; Shen et al. 2020). A randomized controlled clinical trial at Houston Methodist hospital is enrolling COVID-19 patients to determine the therapeutic efficacy of convalescent plasma and to determine the optimal timing of transfusion after the onset of symptoms, frequency of transfusion and required antibody concentration for precise treatment (News Wise 2020).

The therapeutic outcomes of convalescent plasma are attributed to the antibodies that neutralize the SARS-CoV-2 (Fig. 4). Several researchers have identified the human antibodies that block the receptor binding domain (RBD) of the $\mathrm{S}$ protein to abrogate virus interaction with the host cell receptor, a key step of virus host entry. Wang et al. developed SARSCoV-2 neutralizing antibody from SARS-CoV hybridoma, in which four of the candidates showed reactivity with the SARS-CoV-2 S protein. The lead candidate 47D11 showed potent neutralizing activity against both SARS-CoV and SARS-CoV-2 (Wang et al. 2020a). Others isolated potent RBD binding antibodies from COVID-19 patients and evaluated their SARS-CoV-2 neutralizing efficacy. From 149 COVID-19 convalescent patients, only $1 \%$ of the patients had high antibody titers with SARS-CoV-2 neutralizing capability. Further, researchers isolated antibody secreting B cells from the high to moderate titer COVID-19 patients and identified potent antibodies against SARS-CoV-2 RBD in both patient groups. Surprisingly, sequential similarity was 


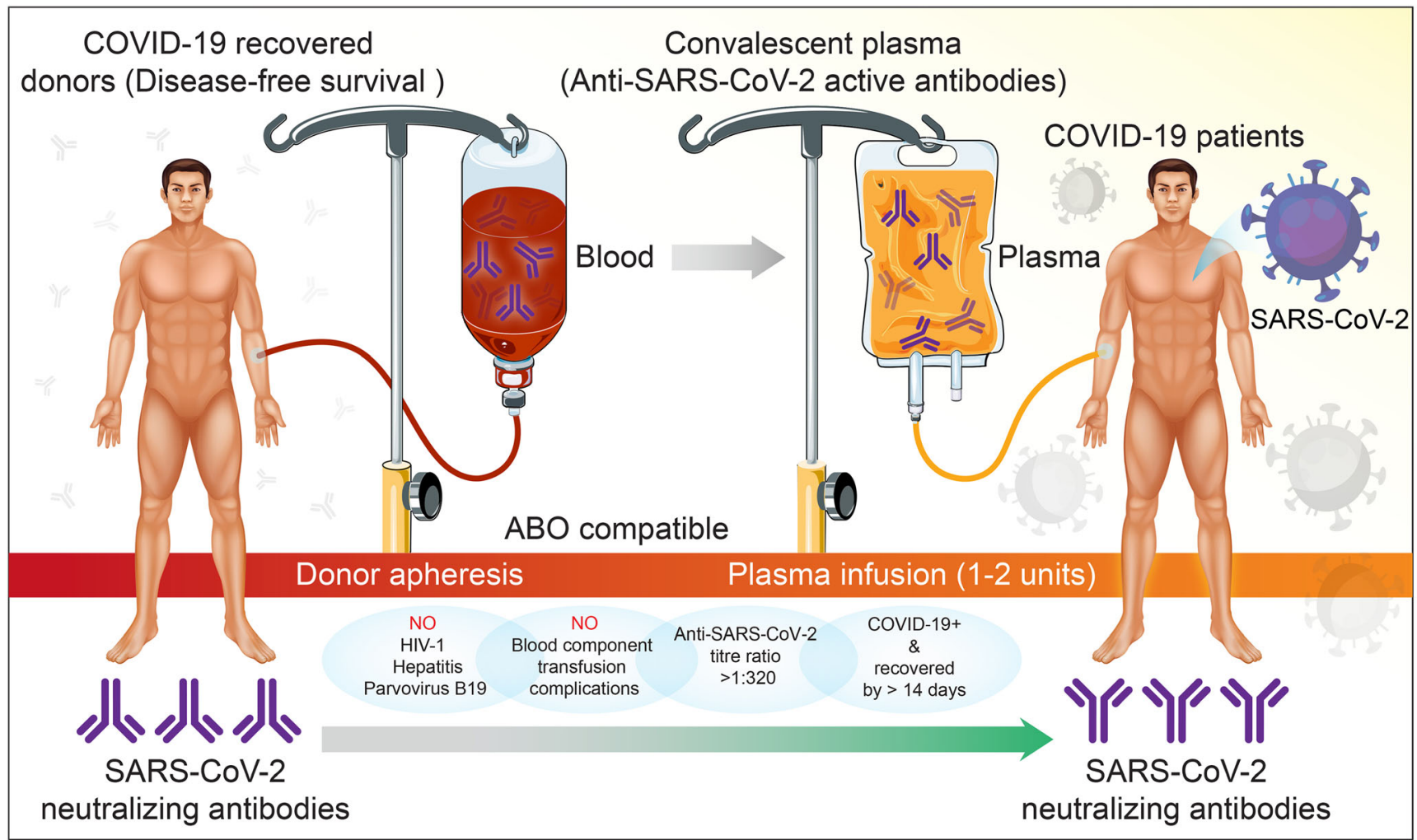

Fig. 4 Convalescent plasma therapy. The use of convalescent plasma to treat COVID-19 requires donor testing of a person who has recovered from disease and has substantial titers of SARS-CoV-2 neutralizing antibodies. The plasma of recovered COVID-19 patients contains SARSCoV-2 antibodies. These are present in plasma, which are collected then used as therapies. Convalescent plasma is safe, specific and effective. This schematic describes how convalescent plasma therapy is administered. It is as follows: (1) Donor apheresis. Blood is collected from the patient and antibody containing plasma is harvested by apheresis. (2)
Plasma infusion. Convalescent plasma is collected from plasma of the donor then administered to the COVID-19 patient intravenously to deliver virus-specific antibodies. The plasma is collected through blood banks and given to blood-type-compatible patients with active SARS-CoV-2 infection. All donors are screened for HIV-1 and for hepatitis viruses and parvovirus B19. There are no other blood components uncovered that could yield secondary complications. The anti-SARS-CoV-2 titer must be at or greater than 1:320. Donors should have no systemic illness for at least 14 days after recovery identified in the epitope binding sites of the neutralizing antibodies from different patients, suggesting that RBD specific antibody with potent antiviral activity had developed in the COVID-19 patients (Robbiani et al. 2020). In another study, scientists isolated a total of 389 RBD specific SARS-CoV-2 neutralizing monoclonal antibodies from the $\mathrm{B}$ cells of two COVID-19 convalescent patients. Two of these antibodies, COV2-2196 and COV2-2130, demonstrated potent SARSCoV-2 neutralization by blocking non-overlapping sites of $\mathrm{RBD}$ on viral $\mathrm{S}$ protein. In mouse models of SARS-CoV-2 infection, COV2-2196 and COV2-2130 treatment alone or in combination protected mice from weight loss and reduced viral load and inflammation in the lungs. COV2-2196 and COV2-2130 also protected rhesus macaques from SARSCoV-2 infection as monotherapy (Zost et al. 2020). Investigators isolated and characterized $206 \mathrm{RBD}$ specific monoclonal antibodies from the B cells of eight SARSCoV-2-infected individuals. The most potent neutralizing antibodies (P2C-1F11, P2B-2F6 and P2C-1A3) showed highest competitive inhibition of ACE2 binding with the RBD from the SARS-CoV-2. Surprisingly, these anti-SARS-CoV-2 antibodies did not cross-react with the RBD from the SARSCoV or MERS-CoV. Hence, competitive inhibition might be a better predictor of antiviral efficacy than virus-neutralizing capacity of the antibody (Ju et al. 2020a). Brouwer et al. isolated 19 monoclonal antibodies from the three convalescent COVID-19 patients that targeted diverse antigenic sites, including RBD and non-RBD epitopes from the SARS-CoV2. A subset of antibodies showed potent nanaomolar neutralizing activity against authentic SARS-CoV-2 (Brouwer et al. 2020). SARS-CoV-2 neutralizing antibodies were also identified by high-throughput single cell sequencing of antigenenriched B cells from convalescent COVID-19 patients. A subset of potent antibodies showed nanomolar neutralizing activity against both pseudo and authentic SARS-CoV-2. Clinical studies with the most potent neutralizing antibody, BD-368-2, are underway (Cao et al. 2020b). In another study, more than 1000 human monoclonal antibodies were isolated from the convalescent COVID-19 patients using a highthroughput pipeline. Out of them, a small fraction of 
antibodies showed strong neutralizing activity against SARSCoV-2. The most potent monoclonal antibody, CC12.1, protected Syrian Hamster against weight loss and viral replication of the SARS-CoV-2 in the lung (Rogers et al. 2020). Together, these studies provide a structural guide for designing vaccines and antibodies as a potential therapy of SARSCoV-2 infection. Human recombinant antibodies were also identified from the healthy individuals using antibody phage display tool. From the 309 unique human recombinant antibodies, several antibodies were able to bind SARS-CoV-2 $\mathrm{RBD}$ and displayed potent inhibition of $\mathrm{S}$ protein binding to the ACE2 receptor expressing cells. Antibodies also neutralized the SARS-CoV-2 infection in VeroE6 cells. Another study suggested a quick development of SARS-CoV-2 neutralizing human recombinant antibodies from healthy donors independent of SARS-CoV-2 recovered patients (Bertoglio et al. 2020). Development of recombinant human antibodies specific for SARS-CoV-2 is essential for the prophylactic or curative treatment of COVID-19. Academic and industrial researchers are exploring almost every available platform for efficient antibody production against SARS-CoV-2 (Renn et al. 2020). Currently, eight SARS-CoV-2 neutralizing antibodies are under clinical investigation that include LYCoV555 (NCT04537910, NCT04411628), JS016 (NCT04441918), REGN-COV2 (NCT04425629, NCT04426695, and NCT04452318), TY027 (NCT04429529), BRII-196 (NCT04479631), BRII-198 (NCT04479644), CT-P59 (NCT04525079), and SCTA01 (NCT04483375). Practically, antibody development is a costly and extensive. Developing successful antibody against SARS-COV-2 quickly requires a new pandemic paradigm, with a fast start and many steps executed in parallel before confirming a successful outcome of another step, which results in elevated financial risk. Further, large scale monoclonal antibodies production and distribution to clinics is challenging. The main factor affecting development of antibodies include SARS-CoV-2 mutation (Starr et al. 2020). Since the onset of COVID-19, several mutations have been identified in the S protein and other ACE2 binding sites of the SARSCoV-2 that affect RBD expression and infectivity. D614G mutation in the S1 protein of SARS-CoV-2 increases the virus infectivity (Korber et al. 2020). Mutations within the antibody binding sites have also been detected (Korber et al. 2020; Pinto et al. 2020). Although the frequency of such mutations is low, they might affect the efficacy of the neutralizing antibodies (Renn et al. 2020; Starr et al. 2020). The use of antibody in combination with non-overlapping epitopes is a promising approach to overcome these limitations. AstraZeneca is developing an antibody combination therapy AZD7442, which is a mixture of two potent antibodies AZD8895 and AZD1061 and is currently in a phase 1 clinical trial (NCT04507256). Similarly, Regeneron Pharmaceutics which developed a mixture of three monoclonal antibodies against Ebola virus, is now developing REGN-COV2, a mixture of REGN10933 and REGN10987 antibodies in collaboration with the National Institute of Allergy and Infectious Disease (NIAID). Currently, REGN-COV2 is under phase 3 clinical trial (NCT04452318).

Vaccines for the Elderly Population The human body's immune system becomes weaker with age, especially in individuals with comorbid conditions such as hypertension, diabetes, kidney, liver, cancer, coronary artery and chronic obstructive lung diseases (Alpert et al. 2019; Pan et al. 2020; Wang et al. 2020b). COVID-19 is commonly viewed as a, "disease of the older people", owing to the exponential risk of age-related mortality (Le Couteur et al. 2020; Promislow 2020). Of the total number of COVID-19 deaths worldwide, almost $50 \%$ are above 65 years of age (Centers for Disease Control and Prevention (CDC) 2020c). This is reflected in the high death rates in Spain (Bonanad et al. 2020) and Italy (Boccardi et al. 2020); both have larger recorded aged populations associated with immunosenescence and comorbid conditions (Wang et al. 2020b; Zhou et al. 2020b). Prominent comorbidities including hypertension, followed by diabetes, coronary heart disease, chronic obstructive lung disease, carcinoma, and chronic kidney disease all attributed to increased mortality in COVID-19 patients (Wang et al. 2020b; Zhou et al. 2020a). The elderly are socially vulnerable to infectious diseases when housed in institutions and can acquire the disease from close contact exposure with their caregivers (Bonanad et al. 2020). During the COVID-19 pandemic, we cannot divert our focus on the vaccine development without considering the elderly population, who typically have one or more underlying disease conditions. The older adults are more susceptible to SARS-CoV-2 infection and develop more severe COVID19. Moreover, with older age, the co-progressions in cellular senescence, immunosenescence and inflammation can lead to deterioration of the immune function, starting with thymal involution (Fagnoni et al. 2000; Fulop et al. 2017). Immunosenescence results from the progressive deterioration of the innate and adaptive immune system which not only diminishes the ability to fight off infections, but also blunts the competence to surmount a vaccine induced antibody or cell-mediated immune response, thus attenuating immunity (Chen et al. 2009). The aging cells may also produce misfolded self-antigens, mitochondrial fragments, extracellular vesicles and senescent cells. These aging processes in turn evoke a pro-inflammatory immune response against selfantigens (Franceschi et al. 2000; Fulop et al. 2017; Franceschi et al. 2018). Additionally, certain immune cells were found to secrete senescence-related components like cytokines, chemokines and extracellular matrix remodeling proteases (Callender et al. 2018). This high inflammatory status aids in promoting the cytokine storm, comprised of IL-6 and other mediators that attribute to the increased 
pathophysiological response to SARS-CoV-2 in elderly individuals (Mueller et al. 2020; Salimi and Hamlyn 2020; Sargiacomo et al. 2020). Furthermore, upregulation of SARS-CoV-2 specific host receptors by senescent cells were also observed (Sargiacomo et al. 2020). Cellular senescence due to telomere shortening in virus-specific memory immune cells reduce $\mathrm{CD} 4+$ and $\mathrm{CD} 8+\mathrm{T}$ cells and regulatory $\mathrm{T}$ cell count (Mueller et al. 2020). The reduced T cells then lead to a shift in T cell subset distribution and loss of CD27 and CD28 co-stimulatory molecule expression, which is considered an underlying mechanism for severe adult COVID-19 pneumonia cases, by increasing susceptibility to infections ( $\mathrm{Li}$ et al. 2019; Scarpa et al. 2020). This reduction or absence of thymopoiesis also exacerbates the cytokine storms (Scarpa et al. 2020). Hence, older individuals have a diminished ability to combat infections along with an impaired ability to develop antibody or cell-mediated immune responses to pathogens, cancer cells and vaccines (Chen et al. 2009). Progress of vaccine development targeting the elderly individuals is slow. This is partly due to the lack of understanding of SARS-CoV-2 mechanisms in immune systems under comorbidity conditions (Pelicioni and Lord 2020). All of these factors are affecting the development of vaccines or the excessively strong immune responses against the SARS-CoV-2 in the elderly (Chen et al. 2009). To develop effective and improved vaccination strategy for older population, adjuvants, higher antigen dose, alternative routes of administration and immunostimulatory agents can be adopted (Weinberger 2018). System biology approach are needed to identify proteins or pathways associated with diminished immune responses which can be stimulated by senolytes and other immunomodulatory drugs. Senolytes can lead to selective apoptosis of the senescent cells to compensate for age-related deficiencies, and thereby improve immunoprotection in aged people (Kirkland and Tchkonia 2017). SARS-CoV-2 vaccines have been made by conjugating adjuvants with the coronavirus $\mathrm{S}$ protein to broaden and induce immune response (Fig. 5). Unique screening systems identified potent adjuvant vaccine targets (American Scientific, 2020). Currently, the Boston Children's Hospital is developing a novel approach to conjugate an adjuvant with the coronavirus $\mathrm{S}$ protein for vaccine development, particularly targeting the elderly population (Centers for Disease Control and Prevention (CDC) 2020c). Additionally, the U.S. FDA is facilitating the evaluation of hyperimmune globulin for elderly patients with COVID-19 (US FDA, 2020c). (Fig. 6).

\section{General Disease Management}

COVID-19 can be managed at home, for patients with mild infection (e.g., fever, cough, and myalgias without dyspnea), or for individuals with asymptomatic infection who are adequately isolated within the outpatient setting. Management of such patients should focus on the prevention of transmission

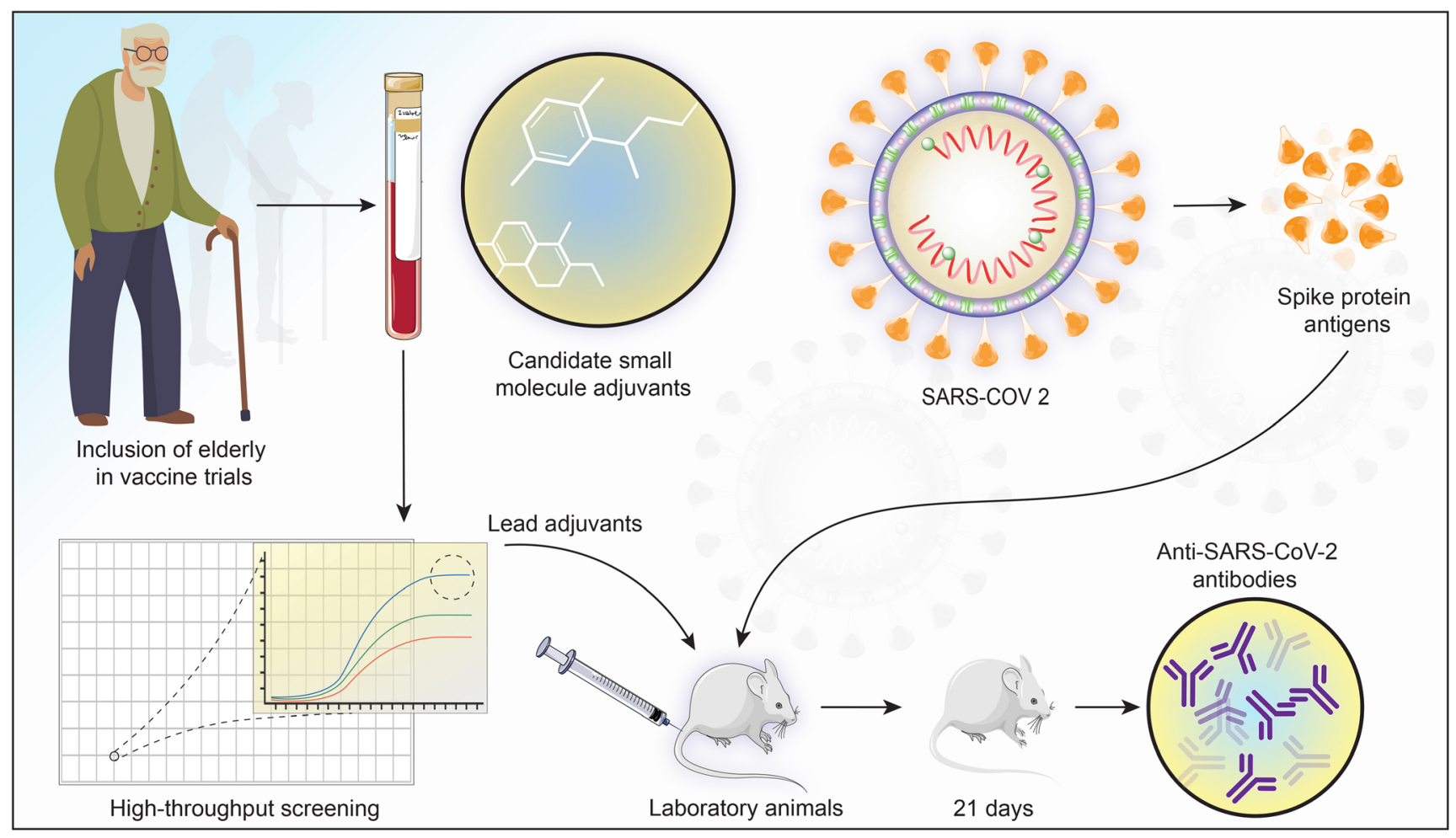

Fig. 5 Vaccines for the elderly. Blood samples are collected from elderly are used to test the immunogenicity of small molecule adjuvant conjugated spike protein as vaccine candidates. The lead adjuvants are tested for their ability to induce humoral and cellular immune responses against SARS-CoV-2 


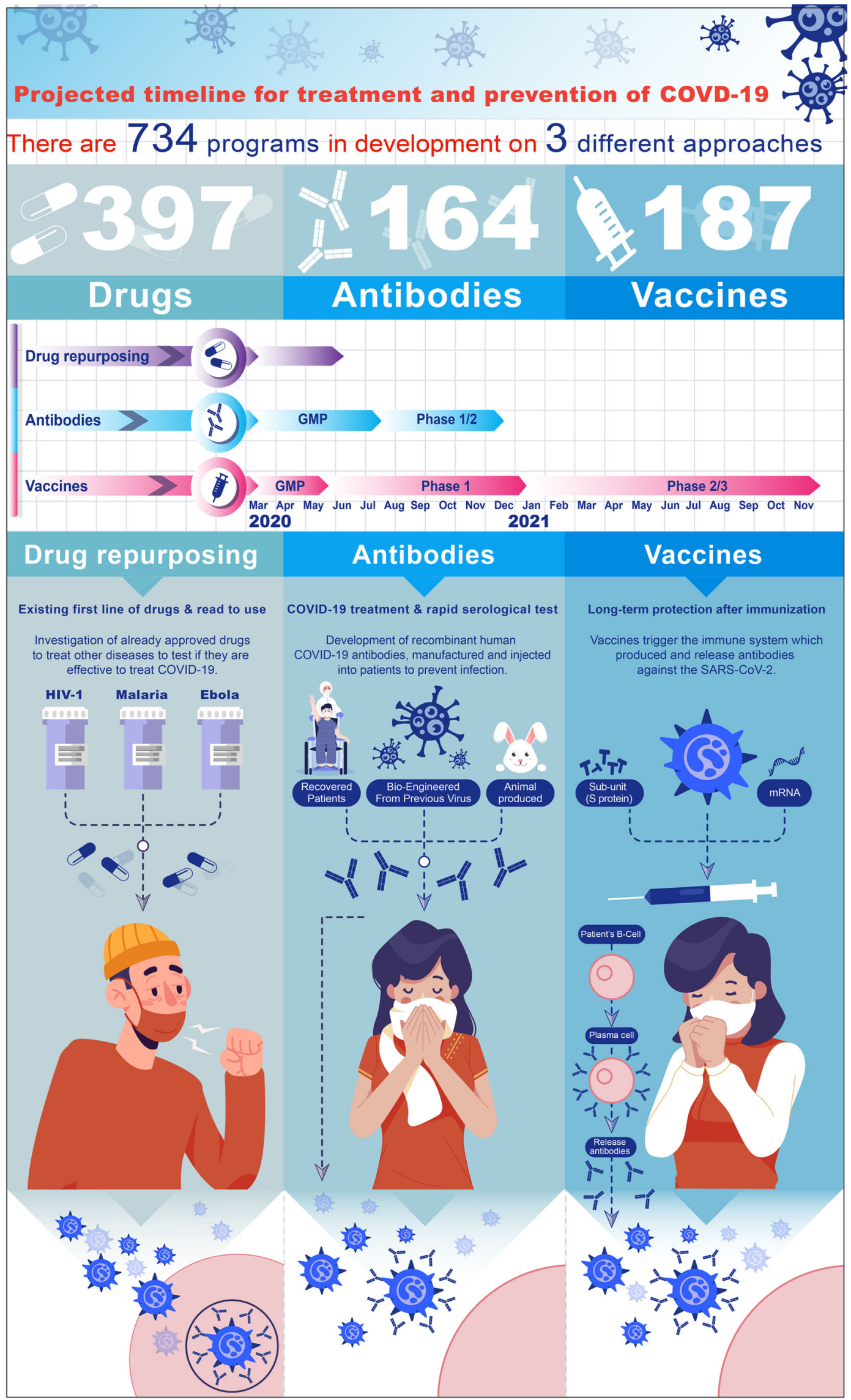


Fig. 6 Treatment and prevention. There are multiple treatment and prevention measures in play for SARS-CoV-2. These include, but are not limited to, repurposing drugs, producing neutralizing antibodies, mobilizing immunity through boosting or modulating antiviral immunity, and by preventing infection through vaccines. Repurposing U.S. FDA approved medication have the shortest turnaround given the extensive background information. Antibodies will be used to sequester viruses after passing clinical trials but may be limited by production scaling. Finally, vaccines will likely take over 18 months to produce and will allow for a secondary adaptive immune response to COVID19 once complete (Bio 2020; Yang et al. 2020a, 2020b)

to others and monitoring for clinical deterioration, which should prompt hospitalization (Cheng et al. 2020; World Health Organization (WHO) 2020e). Management of patients who warrant hospitalization consists of ensuring appropriate infection control and supportive care, including oxygenation and potentially ventilation support for ARDS (World Health Organization (WHO) 2020e). Whether at home or in the hospital, standard precautions include hand and respiratory hygiene, utilization of appropriate PPE consistent with a risk assessment, injection safety practices, safe waste management, proper cleaning of linens, environmental cleaning, and sterilization of patient-care equipment (World Health Organization (WHO) 2020c). Individuals should make sure that the subsequent respiratory hygiene measures are used including proper coverage of nasal and oral emissions with a tissue or an elbow when coughing or sneezing, proper application of a face mask to patients with suspected COVID-19 while they are in waiting/public areas or in cohort rooms, and performance of hand hygiene after contact with respiratory secretions (Centers for Disease Control and Prevention (CDC) 2020d). Each person should apply WHO's My 5 Moments for Hand Hygiene approach before touching a patient, before any clean or aseptic procedure is performed, after exposure to a liquid bodily secretion, after touching a patient, and after touching a patient's surroundings (Sax et al. 2007). Hand hygiene includes either cleansing hands with an alcoholbased hand rub or with soap and water. Alcohol-based hand rubs are preferred if the hands are not visibly soiled, but the washing of hands with soap and water is recommended once they are visibly soiled (Sax et al. 2007). It is vital to make sure that environmental cleaning and disinfection procedures are followed. Thoroughly cleaning environmental surfaces with water and detergent and applying commonly used hospitallevel disinfectants (such as sodium hypochlorite) are effective and sufficient procedures (World Health Organization (WHO) 2020d). Medical devices and equipment, laundry, food service utensils, and medical waste should be managed following safe routine procedures (World Health Organization (WHO) 2020c) Face mask use by the general public has received growing acceptance as a means of reducing the spread of SARS-CoV-2. This measure should be performed in conjunction with good hand hygiene. But global public health messaging on the need for face masks worn by the general public has been inconsistent since the start of the pandemic. The reasons are attributed to cultural standards and magnification of comments by mainstream media outlets. Prior experience with SARS-CoV from 2003 in East Asia, and general social acceptance of wearing facemasks outside of pandemic circumstances helped to make face mask adoption by the general public quickly commonplace throughout the region's dense urban populations. Such acceptance and adoption of face masks came less readily in the West, notably in the United States where the US Surgeon General initially advised against using facemasks for the general public but later encouraged facemask usage when the WHO and CDC revised their positions on the use of face coverings in public. These measures taken together with PPE for health care workers and caregivers, good cleanliness and hygiene standards, social distancing, and use of face covering by the general public can forestall the further evolutions of the COVID-19 pandemic.

\section{Conclusions}

The SARS-CoV-2 pandemic has significantly affected the health, well being and socioeconomic status of the world's population. The beacon of light is the emergence of effective therapeutics and more recently vaccine strategies. Both serve to suppress or eliminate disease signs and symptoms. Remdesivir, dexamethasone, potent virus-specific antibodies, and immune modulators are effective in curtailing disease morbidities. The deployment of effective vaccines are likely in early 2021. Together with public health measures for contact tracing, social distancing, protective masks, and hand washing the pandemic control is soon to be realized. The review has offered the underpinings of a therpauetic road map that will in the time ahead see SARS-CoV-2 elimination.

Acknowledgments We thank Doug Meigs, University of Nebraska Medical Center, for critical review and proof reading of the manuscript. This work was supported by the National Institutes of Health R01 AG043530, P01 DA028555, P30 MH062261, R01 MH115860, R01 NS034249, R01 NS036126, and the Carol Swartz Emerging Neuroscience Fund. CP is funded by the Cancer Australia [APP1145657] and The Garnett Passé and Rodney Williams Foundation.

\section{References}

Alpert A, Pickman Y, Leipold M, Rosenberg-Hasson Y, Ji X, Gaujoux R, Rabani H, Starosvetsky E, Kveler K, Schaffert S, Furman D, Caspi O, Rosenschein U, Khatri P, Dekker CL, Maecker HT, Davis MM, ShenOrr SS (2019) A clinically meaningful metric of immune age derived from high-dimensional longitudinal monitoring. Nat Med 25:487-495 
American Scientific (2020) Coronavirus Vaccines May Not Work for the Elderly - and This Lab Aims to Change That. . https://www. scientificamerican.com/article/coronavirus-vaccines-may-notwork-for-the-elderly-and-this-lab-aims-to-change-that/

Aouba A, Baldolli A, Geffray L, Verdon R, Bergot E, Martin-Silva N, Justet A (2020) Targeting the inflammatory cascade with anakinra in moderate to severe COVID-19 pneumonia: case series. Ann Rheum Dis 79:1381-1382

Arabi YM et al (2018) Treatment of Middle East respiratory syndrome with a combination of lopinavir-ritonavir and interferon-betalb (MIRACLE trial): study protocol for a randomized controlled trial. Trials 19:81

Arons MM, Hatfield KM, Reddy SC, Kimball A, James A, Jacobs JR, Taylor J, Spicer K, Bardossy AC, Oakley LP, Tanwar S, Dyal JW, Harney J, Chisty Z, Bell JM, Methner M, Paul P, Carlson CM, McLaughlin H, Thornburg N, Tong S, Tamin A, Tao Y, Uehara A, Harcourt J, Clark S, Brostrom-Smith C, Page LC, Kay M, Lewis J, Montgomery P, Stone ND, Clark TA, Honein MA, Duchin JS, Jernigan JA, Public Health-Seattle and King County and CDC COVID-19 Investigation Team (2020) Presymptomatic SARS-CoV-2 infections and transmission in a skilled nursing facility. N Engl J Med 382:2081-2090

Backer JA, Klinkenberg D, Wallinga J (2020) Incubation period of 2019 novel coronavirus (2019-nCoV) infections among travellers from Wuhan, China, 20-28 January 2020. Euro Surveill 25:2000062

Baig AM, Khaleeq A, Ali U, Syeda H (2020) Evidence of the COVID-19 virus targeting the CNS: tissue distribution, host-virus interaction, and proposed neurotropic mechanisms. ACS Chem Neurosci 11: 995-998

Barnard DL, Day CW, Bailey K, Heiner M, Montgomery R, Lauridsen L, Chan PK, Sidwell RW (2006) Evaluation of immunomodulators, interferons and known in vitro SARS-coV inhibitors for inhibition of SARS-coV replication in BALB/c mice. Antivir Chem Chemother 17:275-284

Barnes GD, Burnett A, Allen A, Blumenstein M, Clark NP, Cuker A, Dager WE, Deitelzweig SB, Ellsworth S, Garcia D, Kaatz S, Minichiello T (2020) Thromboembolism and anticoagulant therapy during the COVID-19 pandemic: interim clinical guidance from the anticoagulation forum. J Thromb Thrombolysis 50:72-81

Barretto N, Jukneliene D, Ratia K, Chen Z, Mesecar AD, Baker SC (2005) The papain-like protease of severe acute respiratory syndrome coronavirus has deubiquitinating activity. J Virol 79:15189-15198

Beigel JH et al (2020) Remdesivir for the treatment of Covid-19 - preliminary report. N Engl J Med 383:994

Bertoglio $\mathrm{F}$ et al (2020) SARS-CoV-2 neutralizing human recombinant antibodies selected from pre-pandemic healthy donors binding at RBD-ACE2 interface. bioRxiv

Bio (2020) COVID-19 Therapeutic Development Tracker. https://www. bio.org/policy/human-health/vaccines-biodefense/coronavirus/ pipeline-tracker

Biusinesswire (2020) Pfizer and BioNTech Dose First Participants in the U.S. as Part of Global COVID-19 mRNA Vaccine Development Program. https://www.businesswire.com/news/home/ 20200505005474/en/

Blanco-Melo D, Nilsson-Payant BE, Liu WC, Uhl S, Hoagland D, Moller R, Jordan TX, Oishi K, Panis M, Sachs D, Wang TT, Schwartz RE, Lim JK, Albrecht RA, BR TO (2020) Imbalanced Host Response to SARS-CoV-2 Drives Development of COVID-19. Cell 181:10361045.e9

Boccardi V, Ruggiero C, Mecocci P (2020) COVID-19: a geriatric emergency. Geriatr (Basel) 5:24

Bonanad C, Garcia-Blas S, Tarazona-Santabalbina FJ, Diez-Villanueva P, Ayesta A, Sanchis Fores J, Vidan-Austiz MT, Formiga F, ArizaSole A, Martinez-Selles M, Scientific societies of the authors. The contributing authors are members of the following scientific $b$ (2020) Coronavirus: the geriatric emergency of 2020. Joint document of the Section on Geriatric Cardiology of the Spanish Society of Cardiology and the Spanish Society of Geriatrics and Gerontology. Rev Esp Cardiol (Engl Ed) 73:569-576

Borba MGS, Val FFA, Sampaio VS, Alexandre MAA, Melo GC, Brito M, Mourão MPG, Brito-Sousa JD, Baía-da-Silva D, Guerra MVF, Hajjar LA, Pinto RC, Balieiro AAS, Pacheco AGF, Santos JDO Jr, Naveca FG, Xavier MS, Siqueira AM, Schwarzbold A, Croda J, Nogueira ML, Romero GAS, Bassat Q, Fontes CJ, Albuquerque BC, Daniel-Ribeiro CT, Monteiro WM, Lacerda MVG, for the CloroCovid-19 Team (2020) Effect of high vs low doses of Chloroquine Diphosphate as adjunctive therapy for patients hospitalized with severe acute respiratory syndrome Coronavirus 2 (SARS-CoV-2) infection: a randomized clinical trial. JAMA Netw Open 3:e208857

Brayer SW, Reddy KR (2015) Ritonavir-boosted protease inhibitor based therapy: a new strategy in chronic hepatitis $\mathrm{C}$ therapy. Expert Rev Gastroenterol Hepatol 9:547-558

Broggi A, Ghosh S, Sposito B, Spreafico R, Balzarini F, Lo Cascio A, Clementi N, De Santis M, Mancini N, Granucci F, Zanoni I (2020) Type III interferons disrupt the lung epithelial barrier upon viral recognition. Science 369:706-712

Brouwer PJM, Caniels TG, van der Straten K, Snitselaar JL, Aldon Y, Bangaru S, Torres JL, Okba NMA, Claireaux M, Kerster G, Bentlage AEH, van Haaren MM, Guerra D, Burger JA, Schermer EE, Verheul KD, van der Velde N, van der Kooi A, van Schooten J, van Breemen MJ, Bijl TPL, Sliepen K, Aartse A, Derking R, Bontjer I, Kootstra NA, Wiersinga WJ, Vidarsson G, Haagmans BL, Ward AB, de Bree GJ, Sanders RW, van Gils MJ (2020) Potent neutralizing antibodies from COVID-19 patients define multiple targets of vulnerability. Science 369:643-650

Butkeviciute E, Jones CE, Smith SG (2018) Heterologous effects of infant BCG vaccination: potential mechanisms of immunity. Future Microbiol 13:1193-1208

Cai Q et al (2020) Experimental treatment with Favipiravir for COVID19: An Open-label Control Study. Eng (Beijing)

Callaway E (2020) The race for coronavirus vaccines: a graphical guide. Nature 580:576-577

Callender LA, Carroll EC, Beal RWJ, Chambers ES, Nourshargh S, Akbar AN, Henson SM (2018) Human CD8(+) EMRA T cells display a senescence-associated secretory phenotype regulated by p38 MAPK. Aging Cell 17:e12675

Cao B, Wang Y, Wen D, Liu W, Wang J, Fan G, Ruan L, Song B, Cai Y, Wei M, Li X, Xia J, Chen N, Xiang J, Yu T, Bai T, Xie X, Zhang L, Li C, Yuan Y, Chen H, Li H, Huang H, Tu S, Gong F, Liu Y, Wei Y, Dong C, Zhou F, Gu X, Xu J, Liu Z, Zhang Y, Li H, Shang L, Wang K, Li K, Zhou X, Dong X, Qu Z, Lu S, Hu X, Ruan S, Luo S, Wu J, Peng L, Cheng F, Pan L, Zou J, Jia C, Wang J, Liu X, Wang S, Wu X, Ge Q, He J, Zhan H, Qiu F, Guo L, Huang C, Jaki T, Hayden FG, Horby PW, Zhang D, Wang C (2020a) A trial of Lopinavir-ritonavir in adults hospitalized with severe Covid-19. N Engl J Med 382: $1787-1799$

Cao Y et al (2020b) Potent neutralizing antibodies against SARS-CoV-2 identified by high-throughput single-cell sequencing of convalescent Patients' B cells. Cell 182:73-84.e16

Carlson R (2020) BNT162 SARS-CoV-2 Vaccine. Precision Vaccinations https://www.precisionvaccinations.com/vaccines/ bnt162-sars-cov-2-vaccine

Carter MJ, Fish M, Jennings A, Doores KJ, Wellman P, Seow J, Acors S, Graham C, Timms E, Kenny J, Neil S, Malim MH, Tibby SM, Shankar-Hari M (2020) Peripheral immunophenotypes in children with multisystem inflammatory syndrome associated with SARSCoV-2 infection. Nat Med 26:1701-1707

Centers for Disease Control and Prevention (CDC) (2020a) Coronavirus disease 2019 in children - United States, February 12-April 2, 2020. MMWR Morb Mortal Wkly Rep 69:422-426 
Centers for Disease Control and Prevention (CDC) (2020b) Coronavirus Disease 2019 (COVID-19). https://www.cdc.gov/coronavirus/ 2019-ncov/covid-data/covidview/index.html

Centers for Disease Control and Prevention (CDC) (2020c) Weekly Updates by Select Demographic and Geographic Characteristics. https://www.cdc.gov/nchs/nvss/vsrr/covid_weekly/index.htm

Centers for Disease Control and Prevention (CDC) (2020d) Information for Healthcare Professionals about Coronavirus (COVID-19). Coronavirus Disease 2019 (COVID-19) https://www.cdc.gov/ coronavirus/2019-nCoV/hcp/index.html

Chandwani A, Shuter J (2008) Lopinavir/ritonavir in the treatment of HIV-1 infection: a review. Ther Clin Risk Manag 4:1023-1033

Chen WH, Kozlovsky BF, Effros RB, Grubeck-Loebenstein B, Edelman R, Sztein MB (2009) Vaccination in the elderly: an immunological perspective. Trends Immunol 30:351-359

Chen J, Liu D, Liu L, Liu P, Xu Q, Xia L, Ling Y, Huang D, Song S, Zhang D, Qian Z, Li T, Shen Y, Lu H (2020a) A pilot study of hydroxychloroquine in treatment of patients with moderate COVID-19. Zhejiang Da Xue Xue Bao Yi Xue Ban 49:215-219

Chen Z, Hu J, Zhang Z, Jiang S, Han S, Yan D, Zhuang R, Hu B, Zhang Z (2020b) Efficacy of hydroxychloroquine in patients with COVID19: results of a randomized clinical trial. medRxiv

Cheng HY, Jian SW, Liu DP, Ng TC, Huang WT, Lin HH, Taiwan COIT (2020) Contact tracing assessment of COVID-19 transmission dynamics in Taiwan and risk at different exposure periods before and after symptom onset. JAMA Intern Med 180:1156-1163

Cheung KS, Hung IFN, Chan PPY, Lung KC, Tso E, Liu R, Ng YY, Chu MY, Chung TWH, Tam AR, Yip CCY, Leung KH, Fung AYF, Zhang RR, Lin Y, Cheng HM, Zhang AJX, To KKW, Chan KH, Yuen KY, Leung WK (2020) Gastrointestinal manifestations of SARS-CoV-2 infection and virus load in fecal samples from the Hong Kong cohort and systematic review and meta-analysis. Gastroenterology 159:81-95

Chirmule N, Propert K, Magosin S, Qian Y, Qian R, Wilson J (1999) Immune responses to adenovirus and adeno-associated virus in humans. Gene Ther 6:1574-1583

Choy EH, De Benedetti F, Takeuchi T, Hashizume M, John MR, Kishimoto T (2020a) Translating IL-6 biology into effective treatments. Nat Rev Rheumatol 16:335-345

Choy KT, Wong AY, Kaewpreedee P, Sia SF, Chen D, Hui KPY, Chu DKW, Chan MCW, Cheung PP, Huang X, Peiris M, Yen HL (2020b) Remdesivir, lopinavir, emetine, and homoharringtonine inhibit SARS-CoV-2 replication in vitro. Antivir Res 178:104786

Chu CM, Cheng VC, Hung IF, Wong MM, Chan KH, Chan KS, Kao RY, Poon LL, Wong CL, Guan Y, Peiris JS, Yuen KY, Group HUSS (2004) Role of lopinavir/ritonavir in the treatment of SARS: initial virological and clinical findings. Thorax 59:252-256

Chu H, Chan JFW, Wang Y, Yuen TTT, Chai Y, Hou Y, Shuai H, Yang D, Hu B, Huang X, Zhang X, Cai JP, Zhou J, Yuan S, Kok KH, To KKW, Chan IHY, Zhang AJ, Sit KY, Au WK, Yuen KY (2020) Comparative replication and immune activation profiles of SARSCoV-2 and SARS-CoV in human lungs: an ex vivo study with implications for the pathogenesis of COVID-19. Clin Infect Dis 71:1400-1409

Cohen MS (2020) Hydroxychloroquine for the prevention of Covid-19 searching for evidence. N Engl J Med 383:585-586

Colson P, Rolain JM, Raoult D (2020) Chloroquine for the 2019 novel coronavirus SARS-CoV-2. Int J Antimicrob Agents 55:105923

Coronaviridae Study Group of the International Committee on Taxonomy of V (2020) The species severe acute respiratory syndrome-related coronavirus: classifying 2019-nCoV and naming it SARS-CoV-2. Nat Microbiol 5:536-544

Dash PK, Kevadiya BD, Su H, Banoub MG, Gendelman HE (2020) Pathways towards human immunodeficiency virus elimination. EBioMedicine 53:102667
Dastan F, Nadji SA, Saffaei A, Marjani M, Moniri A, Jamaati H, Hashemian SM, Baghaei P, Abedini A, Varahram M, Yousefian S, Tabarsi P (2020) Subcutaneous administration of interferon beta-1a for COVID-19: a non-controlled prospective trial. Int Immunopharmacol 85:106688

de Wilde AH, Jochmans D, Posthuma CC, Zevenhoven-Dobbe JC, van Nieuwkoop S, Bestebroer TM, van den Hoogen BG, Neyts J, Snijder EJ (2014) Screening of an FDA-approved compound library identifies four small-molecule inhibitors of Middle East respiratory syndrome coronavirus replication in cell culture. Antimicrob Agents Chemother 58:4875-4884

Decaro N, Lorusso A (2020) Novel human coronavirus (SARS-CoV-2): a lesson from animal coronaviruses. Vet Microbiol 244:108693108693

Dinnon KH, Leist SR, Schäfer A, Edwards CE, Martinez DR, Montgomery SA, West A, Yount BL, Hou YJ, Adams LE, Gully KL, Brown AJ, Huang E, Bryant MD, Choong IC, Glenn JS, Gralinski LE, Sheahan TP, Baric RS (2020) A mouse-adapted model of SARS-CoV-2 to test COVID-19 countermeasures. Nature 586: 560-566

Duan K, Liu B, Li C, Zhang H, Yu T, Qu J, Zhou M, Chen L, Meng S, Hu Y, Peng C, Yuan M, Huang J, Wang Z, Yu J, Gao X, Wang D, Yu X, Li L, Zhang J, Wu X, Li B, Xu Y, Chen W, Peng Y, Hu Y, Lin L, Liu X, Huang S, Zhou Z, Zhang L, Wang Y, Zhang Z, Deng K, Xia Z, Gong Q, Zhang W, Zheng X, Liu Y, Yang H, Zhou D, Yu D, Hou J, Shi Z, Chen S, Chen Z, Zhang X, Yang X (2020) Effectiveness of convalescent plasma therapy in severe COVID-19 patients. Proc Natl Acad Sci U S A 117:9490-9496

Duda A, Stange A, Luftenegger D, Stanke N, Westphal D, Pietschmann T, Eastman SW, Linial ML, Rethwilm A, Lindemann D (2004) Prototype foamy virus envelope glycoprotein leader peptide processing is mediated by a furin-like cellular protease, but cleavage is not essential for viral infectivity. J Virol 78:13865-13870

European Centre for Disease Prevention and Control (ECDC) (2020) Risk assessment: Outbreak of acute respiratory syndrome associated with a novel coronavirus, Wuhan, China; first update. https:/www. ecdc.europa.eu/en/publications-data/risk-assessment-outbreakacute-respiratory-syndrome-associated-novel-coronavirus

Fagnoni FF, Vescovini R, Passeri G, Bologna G, Pedrazzoni M, Lavagetto G, Casti A, Franceschi C, Passeri M, Sansoni P (2000) Shortage of circulating naive CD8(+) T cells provides new insights on immunodeficiency in aging. Blood 95:2860-2868

Felgenhauer U, Schoen A, Gad HH, Hartmann R, Schaubmar AR, Failing K, Drosten C, Weber F (2020) Inhibition of SARS-CoV-2 by type I and type III interferons. J Biol ChemJ Biol Chem 295: 13958-13964

Feng S, Okuda N, Fujinami T, Takada K, Nakano S, Ohte N (1988) Detection of impaired left ventricular function in coronary artery disease with acceleration index in the first derivative of the transthoracic impedance change. Clin Cardiol 11:843-847

Filocamo G, Mangioni D, Tagliabue P, Aliberti S, Costantino G, Minoia F, Bandera A (2020) Use of anakinra in severe COVID-19: a case report. Int J Infect Dis 96:607-609

Franceschi C, Bonafe M, Valensin S, Olivieri F, De Luca M, Ottaviani E, De Benedictis G (2000) Inflamm-aging. An evolutionary perspective on immunosenescence. Ann N Y Acad Sci 908:244-254

Franceschi C, Garagnani P, Parini P, Giuliani C, Santoro A (2018) Inflammaging: a new immune-metabolic viewpoint for age-related diseases. Nat Rev Endocrinol 14:576-590

Fulop T, Larbi A, Dupuis G, Le Page A, Frost EH, Cohen AA, Witkowski JM, Franceschi C (2017) Immunosenescence and Inflamm-aging as two sides of the same coin: friends or foes? Front Immunol 8:1960

Furuta Y, Komeno T, Nakamura T (2017) Favipiravir (T-705), a broad spectrum inhibitor of viral RNA polymerase. Proc Jpn Acad Ser B Phys Biol Sci 93:449-463 
Gallart JM, Galard R, Catalan R, Arguello JM, Castellanos JM, Schwartz S (1988) Towards an attempt at biological differentiation of endogenous and exogenous depression: a study of beta-endorphins and other parameters (prolactin, growth hormone and dexamethasone repression test) in a cohort of ambulatory depressed patients. Ann Med Psychol (Paris) 146:758-763

Galvan Casas C et al (2020) Classification of the cutaneous manifestations of COVID-19: a rapid prospective nationwide consensus study in Spain with 375 cases. Br J Dermatol 183:71-77

Gautret P, Lagier JC, Parola P, Hoang VT, Meddeb L, Mailhe M, Doudier B, Courjon J, Giordanengo V, Vieira VE, Tissot Dupont H, Honore S, Colson P, Chabriere E, La Scola B, Rolain JM, Brouqui P, Raoult D (2020a) Hydroxychloroquine and azithromycin as a treatment of COVID-19: results of an open-label non-randomized clinical trial. Int J Antimicrob Agents 56:105949

Gautret P, Lagier JC, Parola P, Hoang VT, Meddeb L, Sevestre J, Mailhe M, Doudier B, Aubry C, Amrane S, Seng P, Hocquart M, Eldin C, Finance J, Vieira VE, Tissot-Dupont HT, Honoré S, Stein A, Million M, Colson P, la Scola B, Veit V, Jacquier A, Deharo JC, Drancourt M, Fournier PE, Rolain JM, Brouqui P, Raoult D (2020b) Clinical and microbiological effect of a combination of hydroxychloroquine and azithromycin in 80 COVID-19 patients with at least a six-day follow up: a pilot observational study. Travel Med Infect Dis 34: 101663

Geleris J, Sun Y, Platt J, Zucker J, Baldwin M, Hripcsak G, Labella A, Manson DK, Kubin C, Barr RG, Sobieszczyk ME, Schluger NW (2020) Observational study of Hydroxychloroquine in hospitalized patients with Covid-19. N Engl J Med 382:2411-2418

Giacomelli A, Pezzati L, Conti F, Bernacchia D, Siano M, Oreni L, Rusconi S, Gervasoni C, Ridolfo AL, Rizzardini G, Antinori S, Galli M (2020) Self-reported olfactory and taste disorders in SARS-CoV-2 patients: a cross-sectional study. Clin Infect Dis 71: 889-890

Gilead. (2020) Remdesivir compassionate use application. https:// rdvcugilead.com/

Golonka RM, Saha P, Yeoh BS, Chattopadhyay S, Gewirtz AT, Joe B, Vijay-Kumar M (2020) Harnessing innate immunity to eliminate SARS-CoV-2 and ameliorate COVID-19 disease. Physiol Genomics 52:217-221

Gordon CJ, Tchesnokov EP, Woolner E, Perry JK, Feng JY, Porter DP, Gotte M (2020) Remdesivir is a direct-acting antiviral that inhibits RNA-dependent RNA polymerase from severe acute respiratory syndrome coronavirus 2 with high potency. J Biol Chem 295: 6785-6797

Grasselli G, Zangrillo A, Zanella A, Antonelli M, Cabrini L, Castelli A, Cereda D, Coluccello A, Foti G, Fumagalli R, Iotti G, Latronico N, Lorini L, Merler S, Natalini G, Piatti A, Ranieri MV, Scandroglio AM, Storti E, Cecconi M, Pesenti A, for the COVID-19 Lombardy ICU Network (2020) Baseline characteristics and outcomes of 1591 patients infected with SARS-CoV-2 admitted to ICUs of the Lombardy region, Italy. JAMA 323:1574-1581

Grein J, Ohmagari N, Shin D, Diaz G, Asperges E, Castagna A, Feldt T, Green G, Green ML, Lescure FX, Nicastri E, Oda R, Yo K, QuirosRoldan E, Studemeister A, Redinski J, Ahmed S, Bernett J, Chelliah D, Chen D, Chihara S, Cohen SH, Cunningham J, D’Arminio Monforte A, Ismail S, Kato H, Lapadula G, L'Her E, Maeno T, Majumder S, Massari M, Mora-Rillo M, Mutoh Y, Nguyen D, Verweij E, Zoufaly A, Osinusi AO, DeZure A, Zhao Y, Zhong L, Chokkalingam A, Elboudwarej E, Telep L, Timbs L, Henne I, Sellers S, Cao H, Tan SK, Winterbourne L, Desai P, Mera R, Gaggar A, Myers RP, Brainard DM, Childs R, Flanigan T (2020) Compassionate use of Remdesivir for patients with severe Covid19. N Engl J Med 382:2327-2336

Group RC et al (2020) Dexamethasone in hospitalized patients with Covid-19 - preliminary report. N Engl J MedN Engl J Med
Gu J, Korteweg C (2007) Pathology and pathogenesis of severe acute respiratory syndrome. Am J Pathol 170:1136-1147

Guan WJ, Ni ZY, Hu Y, Liang WH, Ou CQ, He JX, Liu L, Shan H, Lei CL, Hui DSC, du B, Li LJ, Zeng G, Yuen KY, Chen RC, Tang CL, Wang T, Chen PY, Xiang J, Li SY, Wang JL, Liang ZJ, Peng YX, Wei L, Liu Y, Hu YH, Peng P, Wang JM, Liu JY, Chen Z, Li G, Zheng ZJ, Qiu SQ, Luo J, Ye CJ, Zhu SY, Zhong NS, China Medical Treatment Expert Group for Covid-19 (2020) Clinical characteristics of Coronavirus disease 2019 in China. N Engl J Med 382: $1708-1720$

Hamming I, Timens W, Bulthuis ML, Lely AT, Navis G, van Goor H (2004) Tissue distribution of ACE2 protein, the functional receptor for SARS coronavirus. A first step in understanding SARS pathogenesis. J Pathol 203:631-637

Hantak MP, Qing E, Earnest JT, Gallagher T (2019) Tetraspanins: architects of viral entry and exit platforms. J Virol 93: e01429-e01417

Hoffmann M, Mosbauer K, Hofmann-Winkler H, Kaul A, Kleine-Weber H, Kruger N, Gassen NC, Muller MA, Drosten C, Pohlmann S (2020a) Chloroquine does not inhibit infection of human lung cells with SARS-CoV-2. Nature 585:588-590

Hoffmann M, Kleine-Weber H, Schroeder S, Krüger N, Herrler T, Erichsen S, Schiergens TS, Herrler G, Wu N-H, Nitsche A, Müller MA, Drosten C, Pöhlmann S (2020b) SARS-CoV-2 cell entry depends on ACE2 and TMPRSS2 and is blocked by a clinically proven protease inhibitor. Cell 181:271-280.e8

Holshue ML, DeBolt C, Lindquist S, Lofy KH, Wiesman J, Bruce H, Spitters C, Ericson K, Wilkerson S, Tural A, Diaz G, Cohn A, Fox LA, Patel A, Gerber SI, Kim L, Tong S, Lu X, Lindstrom S, Pallansch MA, Weldon WC, Biggs HM, Uyeki TM, Pillai SK (2020) First case of 2019 Novel Coronavirus in the United States. N Engl J Med 382:929-936

Huang C, Wang Y, Li X, Ren L, Zhao J, Hu Y, Zhang L, Fan G, Xu J, Gu X, Cheng Z, Yu T, Xia J, Wei Y, Wu W, Xie X, Yin W, Li H, Liu M, Xiao Y, Gao H, Guo L, Xie J, Wang G, Jiang R, Gao Z, Jin Q, Wang J, Cao B (2020a) Clinical features of patients infected with 2019 novel coronavirus in Wuhan, China. Lancet 395:497-506

Huang J, Song W, Huang H, Sun Q (2020b) Pharmacological therapeutics targeting RNA-dependent RNA polymerase, proteinase and spike protein: from mechanistic studies to clinical trials for COVID-19. J Clin Med 9:1131

Hulme OJ, Wagenmakers E-J, Damkier P, Madelung CF, Siebner HR, Helweg-Larsen J, Gronau Q, Benfield TL, Madsen KH (2020) A Bayesian reanalysis of the effects of hydroxychloroquine and azithromycin on viral carriage in patients with COVID-19. medRxiv

Hung IF et al (2020) Triple combination of interferon beta-1b, lopinavirritonavir, and ribavirin in the treatment of patients admitted to hospital with COVID-19: an open-label, randomised, phase 2 trial. Lancet 395:1695-1704

International Vaccine Institute (2020) IVI, INOVIO, and KNIH to partner with CEPI in a Phase I/II clinical trial of INOVIO's COVID-19 DNA vaccine in South Korea. https://www.ivi.int/ivi-inovio-andknih-to-partner-with-cepi-in-a-phase-i-ii-clinical-trial-of-inovioscovid-19-dna-vaccine-in-south-korea/

Israelow B, Song E, Mao T, Lu P, Meir A, Liu F, Alfajaro MM, Wei J, Dong H, Homer RJ, Ring A, Wilen CB, Iwasaki A (2020) Mouse model of SARS-CoV-2 reveals inflammatory role of type I interferon signaling. J Exp Med 217:e20201241

Jamilloux Y, Henry T, Belot A, Viel S, Fauter M, El Jammal T, Walzer T, Francois B, Seve P (2020) Should we stimulate or suppress immune responses in COVID-19? Cytokine and anti-cytokine interventions. Autoimmun Rev 19:102567

Jiang HW, Zhang HN, Meng QF, Xie J, Li Y, Chen H, Zheng YX, Wang XN, Qi H, Zhang J, Wang PH, Han ZG, Tao SC (2020) SARSCoV-2 Orf9b suppresses type I interferon responses by targeting TOM70. Cell Mol Immunol 17:998-1000 
Jones VG, Mills M, Suarez D, Hogan CA, Yeh D, Bradley Segal J, Nguyen EL, Barsh GR, Maskatia S, Mathew R (2020) COVID-19 and Kawasaki disease: Novel virus and Novel case. Hosp Pediatr 10: $537-540$

Ju B, Zhang Q, Ge J, Wang R, Sun J, Ge X, Yu J, Shan S, Zhou B, Song S, Tang X, Yu J, Lan J, Yuan J, Wang H, Zhao J, Zhang S, Wang Y, Shi X, Liu L, Zhao J, Wang X, Zhang Z, Zhang L (2020a) Human neutralizing antibodies elicited by SARS-CoV-2 infection. Nature 584:115-119

Ju J, Li X, Kumar S, Jockusch S, Chien M, Tao C, Morozova I, Kalachikov S, Kirchdoerfer RN, Russo JJ (2020b) Nucleotide analogues as inhibitors of SARS-CoV Polymerase. Pharmacol Res Perspect 8:e0674.

Kawase M, Shirato K, van der Hoek L, Taguchi F, Matsuyama S (2012) Simultaneous treatment of human bronchial epithelial cells with serine and cysteine protease inhibitors prevents severe acute respiratory syndrome coronavirus entry. J Virol 86:6537-6545

Kevadiya BD, Ottemann B, Mukadam IZ, Castellanos L, Sikora K, Hilaire JR, Machhi J, Herskovitz J, Soni D, Hasan M, Zhang W, Anandakumar S, Garrison J, McMillan J, Edagwa B, Mosley RL, Vachet RW, Gendelman HE (2020) Rod-shape theranostic nanoparticles facilitate antiretroviral drug biodistribution and activity in human immunodeficiency virus susceptible cells and tissues. Theranostics 10:630-656

Khan A, Benthin C, Zeno B, Albertson TE, Boyd J, Christie JD, Hall R, Poirier G, Ronco JJ, Tidswell M, Hardes K, Powley WM, Wright TJ, Siederer SK, Fairman DA, Lipson DA, Bayliffe AI, Lazaar AL (2017) A pilot clinical trial of recombinant human angiotensinconverting enzyme 2 in acute respiratory distress syndrome. Crit Care 21:234

Khan F, Fabbri L, Stewart I, Robinson K, Smyth AR, Jenkins G (2020) A systematic review of Anakinra, Tocilizumab, Sarilumab and Siltuximab for coronavirus-related infections. medRxiv

Khuroo MS (2020) Chloroquine and hydroxychloroquine in coronavirus disease 2019 (COVID-19). Facts, fiction and the hype: a critical appraisal. Int J Antimicrob Agents 56:106101

Kirkland JL, Tchkonia T (2017) Cellular senescence: a translational perspective. EBioMedicine 21:21-28

Kollias A, Kyriakoulis KG, Dimakakos E, Poulakou G, Stergiou GS, Syrigos K (2020) Thromboembolic risk and anticoagulant therapy in COVID-19 patients: emerging evidence and call for action. Br J Haematol 189:846-847

Konno Y, Kimura I, Uriu K, Fukushi M, Irie T, Koyanagi Y, Nakagawa S, Sato K (2020) SARS-CoV-2 ORF3b is a potent interferon antagonist whose activity is further increased by a naturally occurring elongation variant. Cell Rep 32:108185

Korber B et al (2020) Tracking changes in SARS-CoV-2 spike: evidence that D614G increases infectivity of the COVID-19 virus. Cell 182: 812-827.e19

Kulkarni TA, Bade AN, Sillman B, Shetty BLD, Wojtkiewicz MS, Gautam N, Hilaire JR, Sravanam S, Szlachetka A, Lamberty BG, Morsey BM, Fox HS, Alnouti Y, McMillan JEM, Mosley RL, Meza J, Domanico PL, Yue TY, Moore G, Edagwa BJ, Gendelman HE (2020) A year-long extended release nanoformulated cabotegravir prodrug. Nat Mater 19:910-920

Lammers T, Sofias AM, van der Meel R, Schiffelers R, Storm G, Tacke F, Koschmieder S, Brummendorf TH, Kiessling F, Metselaar JM (2020) Dexamethasone nanomedicines for COVID-19. Nat Nanotechnol 15:622-624

Lane JCE et al (2020) Risk of hydroxychloroquine alone and in combination with azithromycin in the treatment of rheumatoid arthritis: a multinational, retrospective study. Lancet Rheumatol 2:e698-e711

Le Couteur DG, Anderson RM, Newman AB (2020) COVID-19 is a disease of older people. J Gerontol A Biol Sci Med Sci 75:e119 e120
Lefkowitz EJ, Dempsey DM, Hendrickson RC, Orton RJ, Siddell SG, Smith DB (2018) Virus taxonomy: the database of the international committee on taxonomy of viruses (ICTV). Nucleic Acids Res 46: D708-D717

Lei X, Dong X, Ma R, Wang W, Xiao X, Tian Z, Wang C, Wang Y, Li L, Ren L, Guo F, Zhao Z, Zhou Z, Xiang Z, Wang J (2020) Activation and evasion of type I interferon responses by SARS-CoV-2. Nat Commun 11:3810

Lescure FX, Bouadma L, Nguyen D, Parisey M, Wicky PH, Behillil S, Gaymard A, Bouscambert-Duchamp M, Donati F, le Hingrat Q, Enouf V, Houhou-Fidouh N, Valette M, Mailles A, Lucet JC, Mentre F, Duval X, Descamps D, Malvy D, Timsit JF, Lina B, van-der-Werf S, Yazdanpanah Y (2020) Clinical and virological data of the first cases of COVID-19 in Europe: a case series. Lancet Infect Dis 20:697-706

Li M, Yao D, Zeng X, Kasakovski D, Zhang Y, Chen S, Zha X, Li Y, Xu L (2019) Age related human T cell subset evolution and senescence. Immun Ageing 16:24

Li L, Zhang W, Hu Y, Tong X, Zheng S, Yang J, Kong Y, Ren L, Wei Q, Mei H, Hu C, Tao C, Yang R, Wang J, Yu Y, Guo Y, Wu X, Xu Z, Zeng L, Xiong N, Chen L, Wang J, Man N, Liu Y, Xu H, Deng E, Zhang X, Li C, Wang C, Su S, Zhang L, Wang J, Wu Y, Liu Z (2020a) Effect of convalescent plasma therapy on time to clinical improvement in patients with severe and life-threatening COVID19: a randomized clinical trial. JAMA 324:460-470

Li Q, Guan X, Wu P, Wang X, Zhou L, Tong Y, Ren R, Leung KSM, Lau EHY, Wong JY, Xing X, Xiang N, Wu Y, Li C, Chen Q, Li D, Liu T, Zhao J, Liu M, Tu W, Chen C, Jin L, Yang R, Wang Q, Zhou S, Wang R, Liu H, Luo Y, Liu Y, Shao G, Li H, Tao Z, Yang Y, Deng Z, Liu B, Ma Z, Zhang Y, Shi G, Lam TTY, Wu JT, Gao GF, Cowling BJ, Yang B, Leung GM, Feng Z (2020b) Early transmission dynamics in Wuhan, China, of Novel Coronavirus-infected pneumonia. N Engl J Med 382:1199-1207

Lieberman NAP, Peddu V, Xie H, Shrestha L, Huang ML, Mears MC, Cajimat MN, Bente DA, Shi PY, Bovier F, Roychoudhury P, Jerome KR, Moscona A, Porotto M, Greninger AL (2020) In vivo antiviral host response to SARS-CoV-2 by viral load, sex, and age. 18:e3000849

Liu B, Li M, Zhou Z, Guan X, Xiang Y (2020) Can we use interleukin-6 (IL-6) blockade for coronavirus disease 2019 (COVID-19)-induced cytokine release syndrome (CRS)? J Autoimmun 111:102452

Lover AA (2020) Quantifying treatment effects of hydroxychloroquine and azithromycin for COVID-19: a secondary analysis of an open label non-randomized clinical trial (Gautret et al, 2020). medRxiv

Lu R, Zhao X, Li J, Niu P, Yang B, Wu H, Wang W, Song H, Huang B, Zhu N, Bi Y, Ma X, Zhan F, Wang L, Hu T, Zhou H, Hu Z, Zhou W, Zhao L, Chen J, Meng Y, Wang J, Lin Y, Yuan J, Xie Z, Ma J, Liu WJ, Wang D, Xu W, Holmes EC, Gao GF, Wu G, Chen W, Shi W, Tan W (2020) Genomic characterisation and epidemiology of 2019 novel coronavirus: implications for virus origins and receptor binding. Lancet 395:565-574

Luca S, Mihaescu T (2013) History of BCG vaccine. Maedica (Bucur) 8: $53-58$

Luo P, Liu Y, Qiu L, Liu X, Liu D, Li J (2020) Tocilizumab treatment in COVID-19: a single center experience. J Med Virol 92:814-818

Lurie N, Saville M, Hatchett R, Halton J (2020) Developing Covid-19 vaccines at pandemic speed. N Engl J Med 382:1969-1973

Machhi J, Herskovitz J, Senan AM, Dutta D, Nath B, Oleynikov MD, Blomberg WR, Meigs DD, Hasan M, Patel M, Kline P, Chang RC, Chang L, Gendelman HE, Kevadiya BD (2020) The natural history, pathobiology, and clinical manifestations of SARS-CoV-2 infections. J NeuroImmune Pharmacol 15:359-386

Mantlo E, Bukreyeva N, Maruyama J, Paessler S, Huang C (2020) Antiviral activities of type I interferons to SARS-CoV-2 infection. Antivir Res 179:104811 
Masters PS (2006) The molecular biology of coronaviruses. Adv Virus Res 66:193-292

Michot JM, Albiges L, Chaput N, Saada V, Pommeret F, Griscelli F, Balleyguier C, Besse B, Marabelle A, Netzer F, Merad M, Robert C, Barlesi F, Gachot B, Stoclin A (2020) Tocilizumab, an anti-IL6 receptor antibody, to treat Covid-19-related respiratory failure: a case report. Ann Oncol 31:961-964

Milken Institute (2020) COVID-19 Treatment and Vaccine Tracker. https://milkeninstitute.org/covid-19-tracker

Miyasaka M (2020) Is BCG vaccination causally related to reduced COVID-19 mortality? EMBO Mol Med 12:e12661

Mizumoto K, Kagaya K, Zarebski A, Chowell G (2020) Estimating the asymptomatic proportion of coronavirus disease 2019 (COVID-19) cases on board the Diamond princess cruise ship, Yokohama, Japan, 2020. Euro Surveill 25:2000180

Molina JM, Delaugerre C, Le Goff J, Mela-Lima B, Ponscarme D, Goldwirt L, de Castro N (2020) No evidence of rapid antiviral clearance or clinical benefit with the combination of hydroxychloroquine and azithromycin in patients with severe COVID-19 infection. Med Mal Infect 50:384

Montalvo Villalba MC, Valdes Ramirez O, Mune Jimenez M, Arencibia Garcia A, Martinez Alfonso J, Gonzalez Baez G, Roque Arrieta R, Rosell Simon D, Alvarez Gainza D, Sierra Vazquez B, Resik Aguirre S, Guzman Tirado MG (2020) Interferon gamma, TGFbeta1 and RANTES expression in upper airway samples from SARS-CoV-2 infected patients. Clin Immunol 220:108576

Moorlag S, Arts RJW, van Crevel R, Netea MG (2019) Non-specific effects of BCG vaccine on viral infections. Clin Microbiol Infect 25:1473-1478

Mueller AL, McNamara MS, Sinclair DA (2020) Why does COVID-19 disproportionately affect older people? Aging (Albany NY) 12: 9959-9981

Mukadam IZ, Machhi J, Herskovitz J, Hasan M, Oleynikov MD, Blomberg WR, Svechkarev D, Mohs AM, Zhou Y, Dash P, McMillan J, Gorantla S, Garrison J, Gendelman HE, Kevadiya BD (2020) Rilpivirine-associated aggregation-induced emission enables cell-based nanoparticle tracking. Biomaterials 231:119669

Mulangu S, Dodd LE, Davey RT Jr, Tshiani Mbaya O, Proschan M, Mukadi D, Lusakibanza Manzo M, Nzolo D, Tshomba Oloma A, Ibanda A, Ali R, Coulibaly S, Levine AC, Grais R, Diaz J, Lane HC, Muyembe-Tamfum JJ, PALM Writing Group, Sivahera B, Camara M, Kojan R, Walker R, Dighero-Kemp B, Cao H, Mukumbayi P, Mbala-Kingebeni P, Ahuka S, Albert S, Bonnett T, Crozier I, Duvenhage M, Proffitt C, Teitelbaum M, Moench T, Aboulhab J, Barrett K, Cahill K, Cone K, Eckes R, Hensley L, Herpin B, Higgs E, Ledgerwood J, Pierson J, Smolskis M, Sow Y, Tierney J, Sivapalasingam S, Holman W, Gettinger N, Vallée D, Nordwall J, PALM Consortium Study Team (2019) A randomized, controlled trial of Ebola virus disease therapeutics. N Engl J Med 381: 2293-2303

Multicenter collaboration group of Department of Science and Technology of Guangdong P, Health Commission of Guangdong Province for chloroquine in the treatment of novel coronavirus $\mathrm{p}$ (2020) Expert consensus on chloroquine phosphate for the treatment of novel coronavirus pneumonia. Zhonghua Jie $\mathrm{He} \mathrm{He} \mathrm{Hu} \mathrm{Xi} \mathrm{Za}$ Zhi 43:185-188

Murthy S, Gomersall CD, Fowler RA (2020) Care for Critically ill Patients with COVID-19. JAMA 323:1499-1500

National Institute of Health (NIH) (2020a) COVID-19 Treatment Guidelines. Interleukin-1 Inhibitors. https://www. covid19treatmentguidelines.nih.gov/immune-based-therapy/ interleukin-1-inhibitors/

National Institute of Health (NIH) (2020b) Coronavirus Disease 2019 (COVID-19) Treatment Guidelines. https://www. covid19treatmentguidelines.nih.gov
Netea MG, Joosten LA, Latz E, Mills KH, Natoli G, Stunnenberg HG, O'Neill LA, Xavier RJ (2016) Trained immunity: a program of innate immune memory in health and disease. Sci 352:aaf1098

News Wise (2020) Study finds COVID-19 convalescent plasma therapy safe, with $76 \%$ patients improving. https://www.newswise.com/ coronavirus/study-finds-covid-19-convalescent-plasma-therapysafe-with-76-patients-improving/?article_id $=732770$

O'Neill LAJ, Netea MG (2020) BCG-induced trained immunity: can it offer protection against COVID-19? Nat Rev Immunol 20:335-337

Pan L, Mu M, Yang P, Sun Y, Wang R, Yan J, Li P, Hu B, Wang J, Hu C, Jin Y, Niu X, Ping R, Du Y, Li T, Xu G, Hu Q, Tu L (2020) Clinical characteristics of COVID-19 patients with digestive symptoms in Hubei, China: a descriptive, cross-sectional, multicenter study. Am J Gastroenterol 115:766-773

Patel TK, Barvaliya M, Kevadiya BD, Patel PB, Bhalla HL (2020) Does adding of Hydroxychloroquine to the standard care provide any benefit in reducing the mortality among COVID-19 patients?: a systematic review. J NeuroImmune Pharmacol 15:350-358

Pedersen SF, Ho YC (2020) SARS-CoV-2: a storm is raging. J Clin Invest 130:2202-2205

Pelicioni PHS, Lord SR (2020) COVID-19 will severely impact older people's lives, and in many more ways than you think! Braz J Phys Ther 24:293-294

Pinto D et al (2020) Structural and functional analysis of a potent sarbecovirus neutralizing antibody. Nature 583:290-295

Promislow DEL (2020) A geroscience perspective on COVID-19 mortality. J Gerontol A Biol Sci Med Sci 75:e30-e33

Puelles VG, Lütgehetmann M, Lindenmeyer MT, Sperhake JP, Wong MN, Allweiss L, Chilla S, Heinemann A, Wanner N, Liu S, Braun F, Lu S, Pfefferle S, Schröder AS, Edler C, Gross O, Glatzel M, Wichmann D, Wiech T, Kluge S, Pueschel K, Aepfelbacher M, Huber TB (2020) Multiorgan and renal tropism of SARS-CoV-2. N Engl J Med 383:590-592

Quiros Roldan E, Biasiotto G, Magro P, Zanella I (2020) The possible mechanisms of action of 4-aminoquinolines (chloroquine/ hydroxychloroquine) against Sars-Cov-2 infection (COVID-19): a role for iron homeostasis? Pharmacol Res 158:104904

Rabaan AA (2017) Middle East respiratory syndrome coronavirus: five years later. Expert Rev Respir Med 11:901-912

Rauch S, Jasny E, Schmidt KE, Petsch B (2018) New vaccine technologies to combat outbreak situations. Front Immunol 9:1963

Ravindra NG, Alfajaro MM, Gasque V, Wei J, Filler RB, Huston NC, Wan H, Szigeti-Buck K, Wang B, Montgomery RR, Eisenbarth SC, Williams A, Pyle AM, Iwasaki A, Horvath TL, Foxman EF, van Dijk D, Wilen CB (2020) Single-cell longitudinal analysis of SARSCoV-2 infection in human bronchial epithelial cells. bioRxiv

Renn A, Fu Y, Hu X, Hall MD, Simeonov A (2020) Fruitful neutralizing antibody pipeline brings Hope to defeat SARS-Cov-2. Trends Pharmacol Sci S0165-6147:30166-30168

Robbiani DF, Gaebler C, Muecksch F, Lorenzi JCC, Wang Z, Cho A, Agudelo M, Barnes CO, Gazumyan A, Finkin S, Hägglöf T, Oliveira TY, Viant C, Hurley A, Hoffmann HH, Millard KG, Kost RG, Cipolla M, Gordon K, Bianchini F, Chen ST, Ramos V, Patel R, Dizon J, Shimeliovich I, Mendoza P, Hartweger H, Nogueira L, Pack M, Horowitz J, Schmidt F, Weisblum Y, Michailidis E, Ashbrook AW, Waltari E, Pak JE, Huey-Tubman KE, Koranda N, Hoffman PR, West AP Jr, Rice CM, Hatziioannou T, Bjorkman PJ, Bieniasz PD, Caskey M, Nussenzweig MC (2020) Convergent antibody responses to SARSCoV-2 in convalescent individuals. Nature 584:437-442

Rogers TF, Zhao F, Huang D, Beutler N, Burns A, He WT, Limbo O, Smith C, Song G, Woehl J, Yang L, Abbott RK, Callaghan S, Garcia E, Hurtado J, Parren M, Peng L, Ramirez S, Ricketts J, Ricciardi MJ, Rawlings SA, Wu NC, Yuan M, Smith DM, Nemazee D, Teijaro JR, Voss JE, Wilson IA, Andrabi R, Briney B, Landais E, Sok D, Jardine JG, Burton DR (2020) Isolation of 
potent SARS-CoV-2 neutralizing antibodies and protection from disease in a small animal model. Science 369:956-963

Roper RL, Rehm KE (2009) SARS vaccines: where are we? Expert Rev Vaccines 8:887-898

Rosenberg ES, Dufort EM, Udo T, Wilberschied LA, Kumar J, Tesoriero J, Weinberg P, Kirkwood J, Muse A, DeHovitz J, Blog DS, Hutton B, Holtgrave DR, Zucker HA (2020) Association of Treatment with Hydroxychloroquine or azithromycin with in-hospital mortality in patients with COVID-19 in New York state. JAMA 323:2493-2502

Sai JK, Suyama M, Kubokawa Y, Matsumura Y, Inami K, Watanabe S (2010) Efficacy of camostat mesilate against dyspepsia associated with non-alcoholic mild pancreatic disease. J Gastroenterol 45:335341

Sajuthi SP et al (2020) Type 2 and interferon inflammation strongly regulate SARS-CoV-2 related gene expression in the airway epithelium. Nat Commun 11:5139

Salazar E, Perez KK, Ashraf M, Chen J, Castillo B, Christensen PA, Eubank T, Bernard DW, Eagar TN, Long SW, Subedi S, Olsen RJ, Leveque C, Schwartz MR, Dey M, Chavez-East C, Rogers J, Shehabeldin A, Joseph D, Williams G, Thomas K, Masud F, Talley C, Dlouhy KG, Lopez BV, Hampton C, Lavinder J, Gollihar JD, Maranhao AC, Ippolito GC, Saavedra MO, Cantu CC, Yerramilli P, Pruitt L, Musser JM (2020) Treatment of Coronavirus disease 2019 (COVID-19) patients with convalescent plasma. Am J Pathol 190: $1680-1690$

Salimi S, Hamlyn J (2020) COVID-19 and crosstalk between the hallmarks of aging. J Gerontol A Biol Sci Med Sci 75:e34-e41

Sargiacomo C, Sotgia F, Lisanti MP (2020) COVID-19 and chronological aging: senolytics and other anti-aging drugs for the treatment or prevention of corona virus infection? Aging (Albany NY) 12:65116517

Sax H, Allegranzi B, Uckay I, Larson E, Boyce J, Pittet D (2007) 'My five moments for hand hygiene': a user-centred design approach to understand, train, monitor and report hand hygiene. J Hosp Infect 67:9-21

Scarpa R, Costa L, Del Puente A, Caso F (2020) Role of thymopoiesis and inflamm-aging in COVID-19 phenotype. Pediatr Neonatol 61: 364-365

Sehnal D, Rose AS, Koca J, Burley S, Sameer V (2018) Mol*: towards a common library and tools for web molecular graphics. Workshop on Molecular Graphics and Visual Analysis of Molecular Data

Shamshirian A, Hessami A, Heydari K, Alizadeh-Navaei R, Ebrahimzadeh MA, Yip GW, Ghasemian R, Sedaghat M, Baradaran H, Mohammadi Yazdi S, Aboufazeli E, Jafarpour H, Dadgostar E, Tirandazi B, Karimifar K, Eftekhari A, Shamshirian D (2020) The role of Hydroxychloroquine in the age of COVID-19: a periodic systematic review and meta-analysis. medRxiv

Sheahan TP et al (2017) Broad-spectrum antiviral GS-5734 inhibits both epidemic and zoonotic coronaviruses. Sci Transl Med 9:eaal3653

Sheahan TP, Sims AC, Leist SR, Schafer A, Won J, Brown AJ, Montgomery SA, Hogg A, Babusis D, Clarke MO, Spahn JE, Bauer L, Sellers S, Porter D, Feng JY, Cihlar T, Jordan R, Denison MR, Baric RS (2020) Comparative therapeutic efficacy of remdesivir and combination lopinavir, ritonavir, and interferon beta against MERS-CoV. Nat Commun 11:222

Shen C, Wang Z, Zhao F, Yang Y, Li J, Yuan J, Wang F, Li D, Yang M, Xing L, Wei J, Xiao H, Yang Y, Qu J, Qing L, Chen L, Xu Z, Peng L, Li Y, Zheng H, Chen F, Huang K, Jiang Y, Liu D, Zhang Z, Liu Y, Liu L (2020) Treatment of 5 critically ill patients with COVID-19 with convalescent plasma. JAMA 323:1582-1589

Shin D, Mukherjee R, Grewe D, Bojkova D, Baek K, Bhattacharya A, Schulz L, Widera M, Mehdipour AR, Tascher G, Geurink PP, Wilhelm A, van der Heden van Noort GJ, Ovaa H, Müller S, Knobeloch KP, Rajalingam K, Schulman BA, Cinatl J, Hummer G, Ciesek S, Dikic I, (2020) Papain-like protease regulates SARSCoV-2 viral spread and innate immunity. Nature 587:657-662
Shuai H, Chu H, Hou Y, Yang D, Wang Y, Hu B, Huang X, Zhang X, Chai Y, Cai JP, Chan JF, Yuen KY (2020) Differential immune activation profile of SARS-CoV-2 and SARS-CoV infection in human lung and intestinal cells: implications for treatment with IFNbeta and IFN inducer. J Inf Secur 81:e1-e10

Spencer JC, Ganguly R, Waldman RH (1977) Nonspecific protection of mice against influenza virus infection by local or systemic immunization with Bacille Calmette-Guerin. J Infect Dis 136:171-175

Spiegel M, Pichlmair A, Martinez-Sobrido L, Cros J, Garcia-Sastre A, Haller O, Weber F (2005) Inhibition of Beta interferon induction by severe acute respiratory syndrome coronavirus suggests a two-step model for activation of interferon regulatory factor 3. J Virol 79: 2079-2086

Srinivasan S, Cui H, Gao Z, Liu M, Lu S, Mkandawire W, Narykov O, Sun M, Korkin D (2020) Structural genomics of SARS-CoV-2 indicates evolutionary conserved functional regions of viral proteins. Viruses 12:360

Stanifer ML, Kee C, Cortese M, Zumaran CM, Triana S, Mukenhirn M, Kraeusslich HG, Alexandrov T, Bartenschlager R, Boulant S (2020) Critical role of type III interferon in controlling SARS-CoV-2 infection in human intestinal epithelial cells. Cell Rep 32:107863

Starr SE, Visintine AM, Tomeh MO, Nahmias AJ (1976) Effects of immunostimulants on resistance of newborn mice to herpes simplex type 2 infection. Proc Soc Exp Biol Med 152:57-60

Starr TN, Greaney AJ, Hilton SK, Ellis D, Crawford KHD, Dingens AS, Navarro MJ, Bowen JE, Tortorici MA, Walls AC, King NP, Veesler D, Bloom JD (2020) Deep mutational scanning of SARS-CoV-2 receptor binding domain reveals constraints on folding and ACE2 binding. Cell 182(1295-1310):e1220

Stoermer M (2020) Homology models of Coronavirus 2019-nCoV 3CLpro protease. ChemRxiv

Synairgen (2020) COVID-19. https://www.synairgen.com/covid-19/

Tang N, Li D, Wang X, Sun Z (2020a) Abnormal coagulation parameters are associated with poor prognosis in patients with novel coronavirus pneumonia. J Thromb Haemost 18:844-847

Tang T, Bidon M, Jaimes JA, Whittaker GR, Daniel S (2020b) Coronavirus membrane fusion mechanism offers a potential target for antiviral development. Antivir Res 178:104792

Tang W et al (2020) Hydroxychloroquine in patients mainly with mild to moderate COVID-19: an open-label, randomized, controlled trial. BMJ 369:m1849

Tatsis N, Tesema L, Robinson ER, Giles-Davis W, McCoy K, Gao GP, Wilson JM, Ertl HC (2006) Chimpanzee-origin adenovirus vectors as vaccine carriers. Gene Ther 13:421-429

te Velthuis AJ, Arnold JJ, Cameron CE, van den Worm SH, Snijder EJ (2010) The RNA polymerase activity of SARS-coronavirus nsp 12 is primer dependent. Nucleic Acids Res 38:203-214

Theerawatanasirikul S, Kuo CJ, Phetcharat N, Lekcharoensuk P (2020) In silico and in vitro analysis of small molecules and natural compounds targeting the $3 \mathrm{CL}$ protease of feline infectious peritonitis virus. Antivir Res 174:104697

Tian S, Xiong Y, Liu H, Niu L, Guo J, Liao M, Xiao SY (2020) Pathological study of the 2019 novel coronavirus disease (COVID-19) through postmortem core biopsies. Mod Pathol 33: $1007-1014$

Udugama B, Kadhiresan P, Kozlowski HN, Malekjahani A, Osborne M, Li VYC, Chen H, Mubareka S, Gubbay JB, Chan WCW (2020) Diagnosing COVID-19: the disease and tools for detection. ACS Nano 14:3822-3835

US Food and Drug Administration (US FDA) (2020a) Recommendations for Investigational COVID-19 Convalescent Plasma. https:// wwwfdagov/vaccines-blood-biologics/investigational-new-drugind-or-device-exemption-ide-process-cber/recommendations-investigational-covid-19-convalescent-plasma

US Food and Drug Administration (US FDA) (2020b) FDA issues emergency use authorization for convalescent plasma as potential 
promising COVID-19 treatment, another achievement in Administration's fight against pandemic. FDA News release https://www.fda.gov/news-events/press-announcements/fda-issuesemergency-use-authorization-convalescent-plasma-potentialpromising-covid-19-treatment

US Food and Drug Administration (US FDA) (2020c) Coronavirus (COVID-19) Update: FDA Coordinates National Effort to Develop Blood-Related Therapies for COVID-19. https://www. fda.gov/news-events/press-announcements/coronavirus-covid-19update-fda-coordinates-national-effort-develop-blood-relatedtherapies-covid-19

UT News (2020) New Delivery Method Could Make Niclosamide an Effective Antiviral to Treat COVID-19. https://news.utexas.edu/ 2020/04/06/new-delivery-method-could-make-niclosamide-aneffective-antiviral-to-treat-covid-19/

Wadman M, Couzin-Frankel J, Kaiser J, Matacic C (2020) How does coronavirus kill? Clinicians trace a ferocious rampage through the body, from brain to toes. Science

Wang TF, Lim W (2016) What is the role of hydroxychloroquine in reducing thrombotic risk in patients with antiphospholipid antibodies? Hematology Am Soc Hematol Educ Program 2016:714-716

Wang C, Li W, Drabek D, Okba NMA, van Haperen R, Osterhaus A, van Kuppeveld FJM, Haagmans BL, Grosveld F, Bosch BJ (2020a) A human monoclonal antibody blocking SARS-CoV-2 infection. Nat Commun 11:2251

Wang D, Hu B, Hu C, Zhu F, Liu X, Zhang J, Wang B, Xiang H, Cheng Z, Xiong Y, Zhao Y, Li Y, Wang X, Peng Z (2020b) Clinical characteristics of 138 hospitalized patients with 2019 Novel Coronavirus-infected pneumonia in Wuhan, China. JAMA 323: 1061-1069

Wang M, Cao R, Zhang L, Yang X, Liu J, Xu M, Shi Z, Hu Z, Zhong W, Xiao G (2020c) Remdesivir and chloroquine effectively inhibit the recently emerged novel coronavirus $(2019-\mathrm{nCoV})$ in vitro. Cell Res 30:269-271

Wang Q, Zhang Y, Wu L, Niu S, Song C, Zhang Z, Lu G, Qiao C, Hu Y, Yuen KY, Wang Q, Zhou H, Yan J, Qi J (2020d) Structural and functional basis of SARS-CoV-2 entry by using human ACE2. Cell 181:894-904.e9

Wang Y, Zhang D, du G, du R, Zhao J, Jin Y, Fu S, Gao L, Cheng Z, Lu Q, Hu Y, Luo G, Wang K, Lu Y, Li H, Wang S, Ruan S, Yang C, Mei C, Wang Y, Ding D, Wu F, Tang X, Ye X, Ye Y, Liu B, Yang J, Yin W, Wang A, Fan G, Zhou F, Liu Z, Gu X, Xu J, Shang L, Zhang Y, Cao L, Guo T, Wan Y, Qin H, Jiang Y, Jaki T, Hayden FG, Horby PW, Cao B, Wang C (2020e) Remdesivir in adults with severe COVID-19: a randomised, double-blind, placebo-controlled, multicentre trial. Lancet 395:1569-1578

Weinberger B (2018) Vaccines for the elderly: current use and future challenges. Immun Ageing 15:3

Winkler ES, Bailey AL, Kafai NM, Nair S, McCune BT, Yu J, Fox JM, Chen RE, Earnest JT, Keeler SP, Ritter JH, Kang LI, Dort S, Robichaud A, Head R, Holtzman MJ, Diamond MS (2020) SARS-CoV-2 infection of human ACE2-transgenic mice causes severe lung inflammation and impaired function. Nat Immunol 21: $1327-1335$

Wölfel R, Corman VM, Guggemos W, Seilmaier M, Zange S, Müller MA, Niemeyer D, Jones TC, Vollmar P, Rothe C, Hoelscher M, Bleicker T, Brünink S, Schneider J, Ehmann R, Zwirglmaier K, Drosten C, Wendtner C (2020) Virological assessment of hospitalized patients with COVID-2019. Nature 581:465-469

World Health Organization (WHO) (2020a) "Solidarity" clinical trial for COVID-19 treatments. https://www.who.int/emergencies/diseases/ novel-coronavirus-2019/global-research-on-novel-coronavirus2019-ncov/solidarity-clinical-trial-for-covid-19-treatments

World Health Organization (WHO) (2020b) Coronavirus disease 2019 (COVID-19) Situation Report - 46. https://www.who.int/docs/ default-source/coronaviruse/situation-reports/20200306-sitrep-46covid-19.pdf?sfvrsn=96b04adf 4

World Health Organization (WHO) (2020c) Infection prevention and control during health care when COVID-19 is suspected. Interim guidance https://wwwwhoint/publicatioinfection-prevention/infection-prevention-and-control-during-health-care-when-novel-coronavirus-(ncov)-infection-is-suspected-20200125

World Health Organization (WHO) (2020d) Cleaning and disinfection of environmental surfaces in the context of COVID-19. Interim guidance https://wwwwhoint/publicatioinfection-prevention/cleaningand-disinfection-of-environmental-surfaces-inthe-context-of-covid19

World Health Organization (WHO). (2020e) Clinical management of severe acute respiratory infection when novel coronavirus $(\mathrm{nCoV})$ infection is suspected. https://wwwwhoint/internalpublicatioinfection-prevention/clinicalmanagement-of-severeacute-respiratory-infection-when-novelcoronavirus-(ncov)-infection-is-suspected

Wrapp D, Wang N, Corbett KS, Goldsmith JA, Hsieh CL, Abiona O, Graham BS, McLellan JS (2020) Cryo-EM structure of the 2019nCoV spike in the prefusion conformation. Science 367:1260-1263

Wu Z, McGoogan JM (2020) Characteristics of and important lessons from the Coronavirus disease 2019 (COVID-19) outbreak in China: summary of a report of 72314 cases from the Chinese Center for Disease Control and Prevention. JAMA 323:1239-1242

Wu C, Liu Y, Yang Y, Zhang P, Zhong W, Wang Y, Wang Q, Xu Y, Li M, Li X, Zheng M, Chen L, Li H (2020) Analysis of therapeutic targets for SARS-CoV-2 and discovery of potential drugs by computational methods. Acta Pharm Sin B 10:766-788

Xu Z, Shi L, Wang Y, Zhang J, Huang L, Zhang C, Liu S, Zhao P, Liu H, Zhu L, Tai Y, Bai C, Gao T, Song J, Xia P, Dong J, Zhao J, Wang FS (2020) Pathological findings of COVID-19 associated with acute respiratory distress syndrome. Lancet Respir Med 8:420-422

Yan R, Zhang Y, Li Y, Xia L, Guo Y, Zhou Q (2020) Structural basis for the recognition of SARS-CoV-2 by full-length human ACE2. Science 367:1444-1448

Yang X, Yu Y, Xu J, Shu H, Xia J, Liu H, Wu Y, Zhang L, Yu Z, Fang M, Yu T, Wang Y, Pan S, Zou X, Yuan S, Shang Y (2020a) Clinical course and outcomes of critically ill patients with SARS-CoV-2 pneumonia in Wuhan, China: a single-centered, retrospective, observational study. Lancet Respir Med 8:475-481

Yang L, Liu W, Yu X, Wu M, Reichert JM, Ho M (2020b) COVID-19 antibody therapeutics tracker: a global online database of antibody therapeutics for the prevention and treatment of COVID-19. Antibody Ther 3:205-212

Yao X, Ye F, Zhang M, Cui C, Huang B, Niu P, Liu X, Zhao L, Dong E, Song C, Zhan S, Lu R, Li H, Tan W, Liu D (2020) In vitro antiviral activity and projection of optimized dosing Design of Hydroxychloroquine for the treatment of severe acute respiratory syndrome Coronavirus 2 (SARS-CoV-2). Clin Infect Dis 71:732739

Yin W, Mao C, Luan X, Shen DD, Shen Q, Su H, Wang X, Zhou F, Zhao W, Gao M, Chang S, Xie YC, Tian G, Jiang HW, Tao SC, Shen J, Jiang Y, Jiang H, Xu Y, Zhang S, Zhang Y, Xu HE (2020) Structural basis for inhibition of the RNA-dependent RNA polymerase from SARS-CoV-2 by remdesivir. Science 368:1499-1504

Yoshikawa T, Hill T, Li K, Peters CJ, Tseng CT (2009) Severe acute respiratory syndrome (SARS) coronavirus-induced lung epithelial cytokines exacerbate SARS pathogenesis by modulating intrinsic functions of monocyte-derived macrophages and dendritic cells. J Virol 83:3039-3048

Young BE, Ong SWX, Kalimuddin S, Low JG, Tan SY, Loh J, Ng OT, Marimuthu K, Ang LW, Mak TM, Lau SK, Anderson DE, Chan KS, Tan TY, Ng TY, Cui L, Said Z, Kurupatham L, Chen MIC, Chan M, Vasoo S, Wang LF, Tan BH, Lin RTP, Lee VJM, Leo YS, Lye DC, for the Singapore 2019 Novel Coronavirus Outbreak 
Research Team (2020) Epidemiologic features and clinical course of patients infected with SARS-CoV-2 in Singapore. JAMA 323: 1488-1494

Yuki K, Fujiogi M, Koutsogiannaki S (2020) COVID-19 pathophysiology: a review. Clin Immunol 215:108427

Zhang L, Lin D, Sun X, Curth U, Drosten C, Sauerhering L, Becker S, Rox K, Hilgenfeld R (2020) Crystal structure of SARS-CoV-2 main protease provides a basis for design of improved alpha-ketoamide inhibitors. Science 368:409-412

Zhou B, She J, Wang Y, Ma X (2020a) A case of Coronavirus disease 2019 with concomitant acute cerebral infarction and deep vein thrombosis. Front Neurol 11:296

Zhou P, Yang XL, Wang XG, Hu B, Zhang L, Zhang W, Si HR, Zhu Y, Li B, Huang CL, Chen HD, Chen J, Luo Y, Guo H, Jiang RD, Liu MQ, Chen Y, Shen XR, Wang X, Zheng XS, Zhao K, Chen QJ, Deng F, Liu LL, Yan B, Zhan FX, Wang YY, Xiao GF, Shi ZL (2020b) A pneumonia outbreak associated with a new coronavirus of probable bat origin. Nature 579:270-273

Zhou $\mathrm{Z}$ et al (2020c) Heightened innate immune responses in the respiratory tract of COVID-19 patients. Cell Host Microbe 27:883-890 e882

Zhu N, Zhang D, Wang W, Li X, Yang B, Song J, Zhao X, Huang B, Shi W, Lu R, Niu P, Zhan F, Ma X, Wang D, Xu W, Wu G, Gao GF,
Tan W, China Novel Coronavirus I, Research T (2020) A Novel Coronavirus from patients with pneumonia in China, 2019. N Engl J Med 382:727-733

Ziebuhr J, Siddell SG (1999) Processing of the human coronavirus 229E replicase polyproteins by the virus-encoded $3 \mathrm{C}$-like proteinase: identification of proteolytic products and cleavage sites common to ppla and pplab. J Virol 73:177-185

Zost SJ, Gilchuk P, Case JB, Binshtein E, Chen RE, Nkolola JP, Schäfer A, Reidy JX, Trivette A, Nargi RS, Sutton RE, Suryadevara N, Martinez DR, Williamson LE, Chen EC, Jones T, Day S, Myers L, Hassan AO, Kafai NM, Winkler ES, Fox JM, Shrihari S, Mueller BK, Meiler J, Chandrashekar A, Mercado NB, Steinhardt JJ, Ren K, Loo YM, Kallewaard NL, McCune BT, Keeler SP, Holtzman MJ, Barouch DH, Gralinski LE, Baric RS, Thackray LB, Diamond MS, Carnahan RH, Crowe JE Jr (2020) Potently neutralizing and protective human antibodies against SARS-CoV2. Nature 584:443-449

Publisher's Note Springer Nature remains neutral with regard to jurisdictional claims in published maps and institutional affiliations. 